\title{
ECONOMICS
}

\section{Financial Integration and the Global Effects of China's Growth Surge}

\author{
by \\ Rod Tyers \\ Business School \\ University of Western Australia, and \\ Research School of Economics \\ Centre for Applied Macroeconomic Analysis (CAMA) \\ Australian National University
}

\author{
Yixiao Zhou \\ Crawford School of Public Policy \\ Australian National University, and \\ School of Economics, Finance and Property \\ Curtin Business School \\ Curtin University
}




\title{
Financial Integration and the Global Effects of China's Growth Surge*
}

\author{
Rod TYERS \\ Business School \\ University of Western Australia, and \\ Research School of Economics \\ Centre for Applied Macroeconomic Analysis (CAMA) \\ Australian National University \\ Yixiao ZHOU \\ Crawford School of Public Policy \\ Australian National University, and \\ School of Economics, Finance and Property \\ Curtin Business School \\ Curtin University
}

January 2019

Key words:

Financial integration, China, imbalances, saving, monetary policy, spill-overs

JEL Codes:

F42, F43, F47

Author best contact details:

Rod Tyers

Winthrop Professor of Economics

UWA Business School

Crawley, WA 6009

Australia

rod.tyers@uwa.edu.au

* Funding for the research described in this paper is from Australian Research Council Discovery Grant No. DP0557885. Useful discussions on the topic with Hongyi Chen and Wenli Chen, Dong He, Song Ligang and Paul Luk are acknowledged, along with comments received at seminars at the Australian National University, the China Center for Economic Research, Peking University and the Hong Kong Institute of Monetary Research. Thanks for assistance with data gathering for this research are due to Ying Zhang. 


\title{
Financial Integration and the Global Effects of China's Growth Surge
}

\begin{abstract}
China's financial openness, as measured by cross border flows and asset ownership, peaked during its 2000s growth surge, as did downward pressure on global interest rates and price levels. This was despite China's restriction of financial inflows to approved FDI and tight controls on private outflows. We analyze the global effects of the growth surge and their dependence on these financial policies by employing a global macro model with national portfolio rebalancing, in which flexibility in asset differentiation is used to index financial integration. The results suggest that, globally, the growth surge raised asset prices, reduced yields and bolstered deflationary pressures, while improving aggregate economic welfare. It is shown that, without capital controls, most surge effects on China would have been moderated substantially while the global impacts would have been larger.
\end{abstract}

\section{Introduction}

China's emergence over recent decades and its ultimate size presage major implications for the functioning of the rest of the global economy, and the advanced economies in particular. Central to the question is the "unbalanced" nature of China's growth surge since the 1990s, which peaked in the early 2000s and saw faster growth in China's supply of merchandise than in its consumption. This had direct, and much analysed, effects on the terms of trade facing other regions. ${ }^{1}$ Yet, in addition to the deflationary forces unleashed in these regions, the associated excess supply of saving also changed the financial terms of trade, contributing to asset price inflation and the observed trend decline in asset yields over the same period. ${ }^{2} 3$ Since the global financial crisis (GFC), and more particularly after 2010, a decline in the level of imbalance in China's growth became apparent. China's production structure has been diversifying away from export-oriented light manufacturing into services to better meet home

\footnotetext{
${ }^{1}$ The literature on the terms of trade consequences for the advanced economies began in the 1990s with the debate over the poor performance of unskilled US workers (Bound and Johnson 1992, Wood 1994, Berman et al. 1994, and Leamer 1996, Wood 2018) and extended into a more complex debate over the apparently declining performance of all but the most highly paid US workers (Haskell et al. 2012, Helpmann et al 2010, Autor et al. 2013). It has also included global modelling studies that kicked off with Krugman (1995) and proceeded to the decomposition studies by Tyers and Yang (1997) and Francois and Nelson (1998) with more detailed follow-up of labour effects by Tyers and Yang (2000), Winchester and Greenaway (2007), Francois and Wignaraja (2008), Harris et al. (2011) and Harris and Robertson (2013), Levchenko and Zhang (2012) and Di Giovanni et al. (2013). Diversity in method notwithstanding, all the global modelling studies find net gains to the rest of the world transmitted via terms of trade effects.

${ }^{2}$ The terms of trade gain transmitted financially has been commonly referred to as the Asian "savings glut". See Bernanke (2005), Chinn and Ito (2007), Choi et al. (2008), Ito (2009), Chinn et al. (2012) and Arora et al. (2014).

${ }^{3}$ These changes abroad were superficially beneficial, though the evidence to date suggests that the gains have been at least partially offset by structural unemployment. For a survey and analysis of the neoclassical and Keynesian effects abroad, see Tyers (2015b).
} 
consumption demand (Lardy 2006; Bowles, 2012). There has been relative growth in Chinese consumption and a decline in its excess saving, thus unwinding some of the global effects of the prior growth surge. Yet the deflationary effects of the surge have been persistent, albeit subsequently compounded by other global developments, including the retreat to money during the GFC and its effects on perceived investment risk, increased automation, the extraordinary global expansion of the largest of the information technology based service companies and an unanticipated energy supply glut, necessitating transitions to unconventional monetary policy (UMP) in Japan, the US and Europe.

The role of financial integration is worth particular attention in analysing the global effects of change in China. Its opening to trade was extensive, necessitated by a very high degree of specialisation in labour intensive manufacturing and hence the need to exchange this for products and services that would meet growing domestic demands. This commenced soon after its transitional reforms of the late 1970s and accelerated following its commitment to a modern taxation system and a de facto fixed exchange rate in 1994. Meanwhile, as reflected by the scale of cross-border financial flows, China appeared to open financially. Foreign direct investment (FDI) played a significant role in financing investment and there were substantial outflows of excess saving into global financial markets. Yet the FDI was state-vetted, entering under mandated partnerships with state owned enterprises (SOEs). On the outflow side, private acquisitions of foreign assets were restricted and the domestic currency non-convertible. This meant that the foreign currency remaining in the banking system, due to the excess of export earnings over import expenditure, had to be acquired by the central bank and deposited abroad as official foreign reserves.

We therefore consider two different types of financial integration. The first, Type 1, reflects the scale of cross border flows as proportions of domestic saving or investment. The second, Type 2 , indicates the weakness of capital controls and, in particular, the ease with which the Chinese collective portfolio can be rebalanced away from official foreign reserves and across foreign regions. China's growth surge contributed substantially to integration of Type 1 but not of Type 2. While the financial effects of the surge are of significant interest to us, our focus in this paper is on the differences in domestic and global effects of the surge that would have arisen had there also been financial integration of Type 2. To explore this we use a parsimonious global macroeconomic model that incorporates bilateral linkages across six regions via both trade and financial flows. 
The model includes a number of innovative elements. First, by allowing for asset differentiation it incorporates optimising financial portfolio management in each region that serves to direct saving from each into investments across all regions. Second, the degree of asset differentiation is quantified, via an elasticity of asset substitution, to reflect financial integration of Type 2. Third, UMP is represented where relevant, placing direct demands on the global markets for long maturity assets that are endogenous to chosen targets. This tends to enhance the spill-over effects of monetary policy (Chen et al. 2014), which proves important because the UMP response raises long maturity asset prices and lowers yields. The consequent rebalancing of portfolios in favour of money then exacerbates the deflationary effects of China's growth surge.

Overall, the results suggest that the surge had significant implications for the advanced regions, transmitted via changes in both financial flows and the international terms of trade. This is consistent with empirical analyses that have revealed large macroeconomic effects. ${ }^{4}$ Moreover, it emerges that the growth surge would have yielded net real income gains not only in China but also, albeit more modestly, in advanced regions. Meanwhile we find that these effects are quite sensitive to the level of China's financial integration. Indeed, the domestic effects of the surge are shown to be considerably moderated in the presence of financial integration of Type 2 , including the scale of the growth surge itself. On the other hand, foreign effects are seen to be amplified by such integration, and particularly the deflationary pressures in the US.

The section to follow places China's 2000s growth surge in the context of the evolution of its policy regimes, its economic structure and coincident developments in the slower-growing advanced economies. Section 3 reviews the corresponding changes in financial structure, openness and external impact. Section 4 then presents the model used for quantitative analysis and Section 5 offers numerical analysis of the foreign effects of China's growth surge. Section 6 considers the sensitivity of these effects to financial integration and conclusions are offered in Section 7.

\section{The Surge and its External Effects}

Outside China, macroeconomic assessments of Asian growth have been dominated by critics worried about the imbalances associated with excess saving (the "savings glut") and the

\footnotetext{
${ }^{4}$ For empirical results that confirm the global significance of changes in China see Eickmeier and Kuehnlenz (2018). Our modelling results are contrary, however, to those of N'Daye et al (2010) and Genberg and Zhang (2010), who find that the international effects of changes in Chinese consumption are small. Their conclusions stem from the use of a model in which spill-over effects stem primarily from trade, and financial flows are only weakly represented.
} 
"upstream" financial flows that stem from it. ${ }^{5}$ China's particular contribution to these upstream financial flows has been variously attributed to capital market distortions, exchange rate "manipulation" and myriad other interventions by the all-pervasive Chinese state to confer unfair advantage on Chinese firms and to raise exports and investment at the expense of household consumption. ${ }^{6}$ To see both sides of these controversies we need to place the growth surge in context.

\subsection{Growth and trade}

Adopting the standard "East Asian" growth model, China was able to move workers from rural poverty to urban locations where they could be combined with capital and imported technology, yielding rapid productivity growth (Song et al. 2011). But the modest skills of these workers required that the product mix comprise only light (labour-intensive) manufactures, unbalancing it relative to consumption and investment demand and thus requiring a rapid expansion in trade. The speed of the growth, combined with lagging social institutions and industrial reform, also induced very high household saving rates and made state owned enterprises very profitable, leading to high corporate saving (Bayoumi et al.2010). This had modest effects on the developed regions prior to the 2000s, before which the scale of China's economy did not rival their own. After China's post-WTO accession, however, an unprecedented accumulation of foreign investment combined with new access to markets in the advanced economies to deliver the growth surge.

As indicated by the real GDP series in Figure 1, the modern Chinese economy has in fact enjoyed three growth surges, the first following the "reform and opening up" from the late 1970s and the second following the implementation of the de facto peg to the US dollar and the taxation reforms of 1994. During the first surge, however, China contributed only two per cent of the global economy. By 2000 this was near ten per cent, with much larger shares of global manufactures production and trade. ${ }^{7}$

\footnotetext{
${ }^{5}$ A substantial literature now either asserts, or depends upon, the "savings glut" hypothesis. Contributions include Bernanke (2005, 2011), Caballero et al. (2008), Caballero (2009), Chinn and Ito (2007), Choi et al. (2008), Chinn et al (2012), Eichengreen (2004) and Lee and McKibbin (2007).

${ }^{6}$ The American literature critical of China's macroeconomic policies is also extensive. Bernanke $(2005,2011)$ offers the outline and Krugman (2010) declares that "China is making all of us poorer". The US macroeconomic position is put in more detail by, amongst others, Lardy $(2006,2012)$ and Bergsten et al. (2008). Similar advocacy of policy-induced "balance" in China's growth can be found, still more formally, in Blanchard and Giavazzi (2006), while it is also recognized that some of the US reaction is mercantilist (Ito 2009).

${ }^{7}$ These are proportions of global GDP in international dollars from the IMF, World Economic Outlook Database.
} 


\subsection{External financial effects}

Implications of the surge for global finance follow from the recognition that, since 1980, Asian economies have contributed about half of the increment to global saving, with China contributing fully a third of the increment since 1990. This is evidence that the shift in global growth toward high-saving Asia, which occurred in the 1980s, accelerated the rate at which the global savings supply curve shifted to the right. If, as the data suggest, the corresponding global investment demand curve shifted by less the Wicksellian (1898) "natural" rate of interest at the global level must have declined. ${ }^{8}$

Long maturity bonds in open and well regulated financial markets arbitrage with other major instruments of private saving and investment and are extensively traded internationally. Their yields tend therefore to be more stable through time than business-cycle driven short yields and their movements highly correlated across the advanced economies, as is evident from Figure 2 (Arora et al. 2014). It is argued by Ito (2013:8) that globalisation has made domestic financial markets are more susceptible to international factors, tending to decouple short-term and longterm interest rates. ${ }^{9}$ Consistent with Bernanke (2005), he concludes that the long-term interest rate is tied down by global saving imbalances and hence reflects the natural rate of interest. This reasoning, and that of Rey (2013), both imply that, when there is free capital mobility, there is inter-regional arbitrage at the long end of the yield curve whereas the short end of the yield curve is conventionally controlled by monetary authorities. ${ }^{10}$ It follows, then, that the rise in Asian saving is a possible explanation for the persistent downward trend in long term bond rates since the $1980 \mathrm{~s}$ that is apparent from Figure 2. ${ }^{11}$

Inside China, the excess saving stemmed from a decline in private consumption as a share of GDP between 2000 and 2008, with this share not picking up until after 2010, as shown in Figure 3. Also indicated in the figure are extraordinary rates of domestic saving from GDP. This suggests a major role for the Chinese financial sector in recycling half its GDP into investment. While investment from abroad has been important, as seed capital in the very

\footnotetext{
${ }^{8}$ Ex ante shifts in saving supply and investment demand cannot be observed. See Tyers (2015b) for a discussion of this.

${ }^{9} \mathrm{He}$ and McCauley (2013) find evidence of "imperfect substitutability along the yield curve" and use it to explore monetary policy spill-over effects, which they see as enlarged by the global integration of long bond markets.

${ }^{10}$ We thank Paul Luk for clarifying this point.

${ }^{11}$ The separation of the series for Japan is associated with its long term current account surplus and the major Yen appreciation shocks of the late 1980s and early 1990s, which established a negative risk premium amongst Japanese savers. In all regions, inflation rates were low throughout the period shown in the figure and so the trend of nominal long rates reflects that of corresponding real rates.
} 
early years and as a source of modern technology later (Sun 2009), total investment has mostly followed the pattern of domestic saving through time. Nonetheless, tremendous growth in the domestic economy and thus in recyclable saving has meant that, while inward FDI continued to expand beyond the 2000s surge, its share in total investment in China has been declining (Figure 4). Meanwhile Chinese policy has ensured that FDI nonetheless retains the largest share of net capital inflow (Figure 5).

Gross flows on China's balance of payments are plotted in Figure 6, including its current account, capital account, change of official foreign reserves, and net flows on its financial account (which here excludes changes in official reserves). In this figure, credits refer to inflows of funds and debits to outflows. During the surge the balance of payments shows a relative boom in current account net credits, offset mostly by a substantial rise in official foreign reserves. The subsequent fall in official foreign reserves stemmed from both a reduction in the imbalance between Chinese production and consumption and hence a decline in the trade surplus, along with a slump in the net inflow of investment funds.

\section{Quantifying Financial Integration}

One way to understand financial integration is to see it as the process through which increases in cross-border arbitrage cause prices in domestic financial markets to adjust more in harmony with foreign markets (Lien and Zhang 2018, Ho 2009). China's comparatively high economic growth rate and the similarly high underlying rates of return it has offered to new capital suggest an increasing trend in capital flows both into and out of its economy. ${ }^{12}$ In our view this is a reflection of Type 1 financial integration, which depends only on the extent to which assets are traded and owned externally. Indeed, Type 1 financial integration might best be measured from flow data by a combination of the ratio of investment from abroad to total domestic investment or domestic GDP and the ratio of saving directed to investment abroad to total domestic saving or domestic GDP. From asset stock data corresponding measures are available.

By contrast, in Type 2 financial integration, the focus is on the flexibility with which inward flows can be directed across domestic investments and outward flows can be directed across a range of asset types and destination economies. An economy that is open in this way is likely

\footnotetext{
${ }^{12}$ Huang et al. (2010) and Garcia-Herrero (2015) assert that the trend in such flows indicate that China's capital account has become more open in recent years, yet the gross flows in Figure 5 suggest a subsequent reversal of this trend.
} 
to have a more globally diversified collective asset portfolio. This is not achieved via officially sanctioned FDI on the inflow side and outflows driven by official foreign reserve accumulation, even though these yield high values for Type 1 integration. Type 2 financial integration yields freer arbitrage, allowing asset prices in domestic financial markets to adjust more in harmony with foreign markets.

Quantifying financial integration depends on both de facto and de jure measures, where de jure measures reflect official capital control policies de facto measures indicate actual practice. A range of possible de facto measures for China is shown in Figure 7. These suggest that, during the surge period, there were substantial increases in Type 1 integration but that the pattern since then has been mixed. Considering stock measures, the foreign-owned capital stock rose as a share of GDP while the corresponding share of Chinese-owned capital abroad fell. The inward FDI stock fell while the outward FDI stock rose, though by contrast, the stock of inward portfolio assets rose while that of outward portfolio assets fell. This contrast is most evident after the growth surge, signalling important roles for the "belt and road" initiative and improved access by foreigners to portfolio assets on China's two stock markets (Lim 2017).

Turning to flow measures that indicate Type 1 financial integration, the final graph in Figure 7 is constructed as the weighted sum of the quotient of financial outflows with total domestic saving and the quotient of financial inflows with total domestic investment. This shows a large peak during the growth surge and a decline thereafter, notwithstanding a modest recovery postGFC. Meanwhile, also after the surge, there was significant diversification of assets away from the concentration on foreign reserves. The shares of the FDI stock, portfolio assets, other assets, and foreign reserves in total assets change from 7, 7, 15 and 72 per cent to 21, 7, 25 and 46 per cent, respectively. ${ }^{13}$ These changes suggest increases in Type 2 financial integration, at least to the extent that they have allowed portfolio diversification.

More direct assessments of capital control are available from the two the two de jure measures of capital control offered in Figure 8. These are calculated based on the codification of information provided in the IMF's Annual Report on Exchange Rate Arrangements and Restrictions (AREAER). While there is no change in the Chinn-Ito index (Chinn and Ito 2006), that by Fernandez et al. (2016) does show some relaxation of controls in recent years, though not during the growth surge.

\footnotetext{
${ }^{13}$ Total assets consist of direct investment assets (FDI stock), portfolio investment assets, financial derivative assets, other assets and reserve assets. The value of financial derivate assets is much smaller than other types of assets and is therefore omitted in Figure 7 and the discussion in the main text.
} 
These measures confirm that China opened significantly by Type 1 measures but did not act to raise the level of Type 2 integration until after the surge and the GFC. In our analysis below we ask how the global effects of China's growth surge would have been different had the extent of Type 2 financial integration been greater.

\section{Modelling Financial Interdependence}

A multi-region general equilibrium structure is used that centres on the global financial capital market. ${ }^{14}$ It is assumed that the financial products of each region are differentiated and that portfolio managers assign new net saving across regions so as to maximise expected portfolio returns given this differentiation. This retains Feldstein-Horioka (1980) home bias while allowing significant redirections in financial flows at the margin. It also allows the level of global financial market integration to be parameterised by varying this degree of differentiation. The scale of short run spill-over effects associated with growth performance, excess saving and monetary policy therefore depend on it.

Although there is a tendency for financial flows to move the global economy toward interest parity, this differentiation leaves this process incomplete in the lengths of run considered. At the same time, regional rates of return on equity investments depart from regional bond yields, the former reflecting expected rates of return on installed capital and the latter short run equilibrium in regional financial markets between savers, indebted governments and investors. Within each region the demand for money is driven by a "cash in advance" constraint applying across the whole of GDP and a wealth effect whereby portfolio expansion requires a sustained liquid share, comprising non-yielding money. Thus, in every region, home money is held in a portfolio with long maturity bonds, which are claims over physical capital and government debt across the regions. ${ }^{15}$ The opportunity cost of holding money is the yield on these long bonds. On the supply side of the money market, in regions with unconventional monetary policy, expansions raise demand for long maturity bonds, reducing their yields and hence reducing the opportunity cost of holding money.

\footnotetext{
${ }^{14}$ The model used is a more advanced variant on that used in Tyers (2015a). That model assumed a perfectly integrated global bond market and so tended to generate unrealistically large spill-over effects. Here, all financial products, including government bonds, are represented as regionally differentiated and so there is no perfectly integrated global market for any asset class. Also, this model introduces unconventional monetary, which sees monetary expansions directly affecting the markets for long maturity assets.

${ }^{15}$ Expectations are exogenous in the model and are formed over future values of home nominal disposable income, the rate of inflation, the real post-tax rate of return on home assets and bilateral real exchange rate alignment.
} 
Six regions are identified: the US, the EU, Japan, China, Australia and the Rest of the World, though the focus of this paper is on the first four. ${ }^{16}$ Each region supplies a single product that is also differentiated from the products of the other regions. On the supply side, there are three primary factors with "production" labour $(L)$ a partially unemployed variable factor while the stocks of physical capital $(K)$ and skill $(S)$ are fixed and fully employed. Collective households are net savers with reduced form consumption depending on current and expected future disposable income and the home interest rate. Aggregate consumption is subdivided via a single CES structure between the products of all the regions. The following offers detail on the aspects of the model central to this analysis. ${ }^{17}$

\subsection{Financial markets}

Here the modelling departs from convention by incorporating explicit portfolios of assets from all regions. Data on regional saving and investment for 2016 is first combined with that on international financial flows to construct an initial matrix to allocate total domestic saving in each region to investment across all the regions. From this is derived a corresponding matrix of initial shares of region i's net (private and government) saving that are allocated to the local savings supply that finances investment in region $j, i_{i j}^{S O}$. When the model is shocked, the new shares are calculated so as to favour investment in regions, $j$, with comparatively high after tax yields, generally implying high expected real gross rates of return, $r^{c e}$. This is calculated as:

$$
r_{i}^{c e}=r_{i}^{c}+\hat{e}_{i}^{e}=\frac{P_{i}^{P} M P_{i}^{K}}{P_{i}^{K}}\left(\frac{\varphi_{i}^{0}}{\varphi_{i}}\right)+\hat{e}_{i}^{e},
$$

where $P_{i}^{K}$ is the price of capital goods, which in this model are linked by an exogenous factor to $P_{i}^{P}$, the producer price of the region's generic good. ${ }^{18}$ The (exogenous) expected proportional change in the real exchange rate is $\hat{e}_{i}^{e}$. A further adjustment is made using an interest premium factor, $\varphi_{i}$, that is defined relative to the US $\left(\varphi_{U S}=1\right)$. This permits consideration of the effects of changes in sovereign risk in association with the fiscal balance. Increments to regional sovereign risk cause investments in those regions to be less attractive.

\footnotetext{
${ }^{16}$ The EU is modeled as the full 26 and it is assumed that this collective has a single central bank.

${ }^{17}$ The more routine components of the model are shared with an earlier version that uses a somewhat less developed financial structure (Tyers 2015a, Appendix 1) and an updated version (the appendix to Tyers and Zhou 2018).

${ }^{18}$ The producer price level is the factory door price of the regional good, which differs in this model from the GDP price level due to indirect taxation. See Tyers (2015a: Appendix 1) for an explanation of this.
} 


$$
\varphi_{i}=\varphi_{i}^{0}\left[\left(\frac{G_{i}}{T_{i}} / \frac{G_{U S}}{T_{U S}}\right)\right]^{\phi_{i}}, \quad \forall i \neq " U S ",
$$

where $\phi_{i}$ is an elasticity indicating sensitivity to sovereign risk.

In region $i$, then, the demand for investment financing depends on the ratio of the expected rate of return on installed capital, $r_{i}^{c e}$ and a domestic market clearing bond yield or financing rate, $r_{i}$

(3) $\frac{I_{i}^{D}}{I_{i}^{0}}=\left(\frac{r_{i}^{c e}}{r_{i}}\right)^{\varepsilon_{i}^{I}}$,

where $\varepsilon_{i}^{I}$ is a positive elasticity enabling the relationship to reflect Tobin's Q-like behaviour. This investment demand is then matched in each region by a supply of saving that incorporates contributions from all regional households.

Region $i$ 's portfolio manager allocates the proportion $i_{i j}^{\mathrm{S}}$ of its annual (private plus government) saving to new investments in regions $j$, such that $\sum_{j} i_{i j}^{S}=1 .{ }^{19}$ Because the newly issued equity is differentiated across regions based on un-modelled and unobserved region-specific properties, their services are combined via a constant elasticity of substitution (CES) function specific to each regional portfolio manager. Thus, region i's household portfolio management problem is to choose the shares, $i_{i j}^{S}$, of its private saving net of any government deficit, $S_{i}^{D}=S_{i}^{P}+T^{D}+T^{I}-G$, which are to be allocated to the assets of region $j$ so as to maximise a CES composite representing the value of the services yielded by these assets:

$$
\max _{\substack{i_{i j}^{S}\\}} U_{i}^{F}=S_{i}^{D}\left[\sum_{j} \alpha_{i j}\left(i_{i j}^{S}\right)^{-\rho_{i}}\right]^{-\frac{1}{\rho_{i}}} \text { such that } \sum_{j} i_{i j}^{S}=1 .
$$

Here $\alpha_{i j}$ is a parameter that indicates the benefit to flow from region $i$ 's investment in region $j$. The CES parameter, $\rho_{l}$, reflects the preparedness of region $i$ 's household to substitute between the assets it holds. To induce rebalancing in response to changes in rates of return the $\alpha_{i j}$ are

\footnotetext{
${ }^{19}$ The manager does not re-optimise over total holdings every year. This is because the model is deterministic and risk is incorporated only via exogenous premia, so the motivations for continuous short run rebalancing, other than the arrival of new saving, are not represented.
} 
made dependent on ratios of after-tax yields in destination regions, $j$, and the home region, $i$, via: ${ }^{20}$

$$
\alpha_{i j}=\beta_{i j}\left(\frac{r_{j} / \tau_{j}^{K}}{r_{i} / \tau_{i}^{K}}\right)^{\lambda_{i}} \quad \forall i, j, \quad \lambda_{i}>0 \quad \forall i
$$

Here, $\tau_{i}^{K}$ is the power of the capita income tax rate in region $i$. This relationship indicates the responsiveness of portfolio preferences to yields, via the (return chasing) elasticity $\lambda_{l}$. The allocation problem, thus augmented, is:

$$
\max _{i_{i j}^{S}} U_{i}^{F}=S_{i}^{D}\left[\sum_{j} \beta_{i j}\left(\frac{r_{j} / \tau_{j}^{K}}{r_{i} / \tau_{i}^{K}}\right)^{\lambda_{i}}\left(i_{i j}^{S}\right)^{-\rho_{i}}\right]^{-\frac{1}{\rho_{i}}} \text { such that } \sum_{j} i_{i j}^{S}=1 .
$$

Solving for the first order conditions we have, for region i's investments in regions $j$ and $k$ :

$$
\frac{i_{i j}^{S}}{i_{i k}^{S}}=\left(\frac{\beta_{i j}}{\beta_{i k}}\right)^{\frac{1}{1+\rho_{i}}}\left(\frac{r_{j} / \tau_{j}^{K}}{r_{k} / \tau_{k}^{K}}\right)^{\frac{\lambda_{i}}{1+\rho_{i}}}
$$

This reveals that region i's elasticity of substitution between the bonds of different regions is $\sigma_{i}^{I}=\lambda_{i} /\left(1+\rho_{i}\right)>0$, which has two elements. The return-chasing behaviour of region $i$ 's household $\left(\lambda_{l}\right)$ and the imperfect substitutability of regional bonds, and therefore the sluggishness of portfolio rebalancing $\left(\rho_{i}\right)$. For the purposes of this analysis the values of $\sigma_{i}^{I}$ are seen as indicating the extent of each region's integration with global financial markets. The optimal share of the net domestic saving of region $i$ that is allocated to assets in region $j$ then follows from (8) and the normalisation condition, that $\sum_{k} i_{i k}^{S}=1$ :

$$
i_{i j}^{S}=\frac{1}{\sum_{k}\left(\frac{\beta_{i k}}{\beta_{i j}}\right)^{\frac{\sigma_{i}^{I}}{\lambda_{i}}}\left(\frac{r_{k} / \tau_{k}^{K}}{r_{j} / \tau_{j}^{K}}\right)^{\sigma_{i}^{I}}} .
$$

The key matrix for calibration is $\left[\beta_{i j}\right]$. These elements are readily available, first, by noting that only relative values are required and hence, for each region of origin, $i$, one value can be

\footnotetext{
${ }^{20}$ Note that region $i$ 's market bond yield, $r_{i}$, is determined concurrently and indicates the replacement cost of capital in region $i$ and therefore the opportunity cost for region $i$ 's household of investment in region $j$.
} 
set to unity, and second, by making the assumption that the initial database has the steady state property that the net rates of return in regions $j$ are initially the same as the market bond yield, $r_{j}$. Then, since in the base data $r_{i j}^{e 0}=r_{j}^{0}, r_{i k}^{e 0}=r_{k}^{0}$, the $\beta_{i j}$ s are available from a modified (6):

\subsection{Regional money market equilibrium}

In each region the demand for domestic money as a financial asset is driven by a "cash in advance" constraint applying across the whole of GDP and home money is held in a portfolio with regionally differentiated long maturity bonds, which are claims over physical capital and government debt across the regions. Since portfolios are dominated by long maturity assets, the opportunity cost of holding money is the long bond yield, which is modelled as emerging from equilibrium in a thus weakly segmented global market for loanable funds. Central banks derive monetary expansions in regionally specific proportions from conventional monetary policy and from UMP, with reliance on the market segmentation theory of the yield curve (Johnson et al. 2010) to ensure that conventional monetary policy has no direct impact on the market for long term bonds. Short rates are therefore not modelled explicitly, rather the monetary base in each region is determined as endogenous to the target of monetary policy and an exogenous parameter determines the share of any change in the monetary base that takes the form of long asset balance sheet expansion. UMP expansions raise home long maturity asset prices and lower long yields, causing imperfect spill-overs across regions due to global arbitrage that is only partially constrained by asset differentiation.

The cash-in-advance constraint is assumed to generate transactions demand for home money across all components of gross (including intermediate) output. Transactions demand is then augmented by the real purchasing power of financial wealth, to account for the observed dominance of financial transactions over money demand. ${ }^{21}$ The opportunity cost of holding home money is set at the nominal after-tax yield on home long term bonds. ${ }^{22}$ Real money balances are measured in terms of purchasing power over home products at the GDP price, $P^{Y}$.

\footnotetext{
${ }^{21}$ The inclusion of financial wealth in the money demand equation follows Ragot (2014) and Mena and Tirelli (2017), who incorporate Baumol (1952) - Tobin (1956) behaviour.

22 Thus, it is assumed here that the opportunity cost of holding money is measured by the long bond yield, which is the dominant determinant of non-money portfolio yields. Short rates, at least as they have a role in conventional monetary policy, are here embedded in the determination of the monetary base. While housing investment can be sensitive to short rates in economies where most mortgage contracts have variable rates, the assumption that investment financing depends on the long maturity market is a simplifying abstraction in this global analysis.
} 


$$
m_{i}^{D}=a_{i}^{M D}\left(y_{i}\right)^{\varepsilon_{i}^{M Y}}\left(w_{i}^{F}\right)^{\varepsilon_{i}^{M W}}\left(\frac{r_{i}\left(1+\pi_{i}^{e}\right)}{\tau_{i}^{K}}\right)^{-\varepsilon_{i}^{M R}}=\frac{M_{i}^{S}}{P_{i}^{Y}}=\frac{\mu_{i} M_{i}^{B}}{P_{i}^{Y}} .
$$

For region $i, y_{i}$ is real, regional gross output, as distinct from real GDP since intermediates are transacted as well as goods and services entering final demand. Real financial wealth is $w_{i}^{F}$, $\tau_{i}^{K}$ is the power of the capital income tax rate in region $i$ and $\pi_{i}^{e}$ is the expected inflation rate of the consumer price level, $P^{C}$, defined as a CES aggregate of home and imported consumer prices. Real financial wealth or assets, $w^{F}$, is represented as the present value of an infinite stream of real dividends that are equal to after-tax returns on the capital stock, at the expected real rate of return on installed capital, $r^{c e}$, discounted at the current real financing rate, $r$. A price adjustment is also made for relative inflation or deflation of capital goods prices, which raise or lower the purchasing power of financial wealth over home products.

$$
w_{i}^{F}=\frac{r_{i}^{c e}\left(1-t_{i}^{K}\right)\left(P_{i}^{K} / P_{i}^{Y}\right) K}{r_{i}} .
$$

Thus, money demand is driven by transactions $(y)$, portfolio expansion $\left(w^{F}\right)$ and portfolio rebalancing as it affects the liquid component (driven by the opportunity cost, $r$ ).

On the supply side of the money market, the proportion of expansions that occur via the purchase of long maturity assets (UMP) is parameterised. Conventional expansions directly affect the money supply while UMP expansions affect both it and the long end of the yield curve. UMP expansions raise home long maturity asset prices and lower long yields, causing imperfect spill-overs due to global arbitrage that is only partially constrained by asset differentiation. ${ }^{23}$

Regional financial market clearance requires that the home financial market in each region clears separately and this implies global financial market clearance. For region $i$, the nominal value of domestic investment, $I_{i}^{D}$, represents the sum total of all domestic long bond issues. This is then equated with demand for those bonds from home and foreign (net private and government) savings, along with demands for home long bonds that arise from the

\footnotetext{
${ }^{23}$ By contrast, conventional monetary policy involves trade in short term instruments which has no direct, immediate impact on the market for long term bonds, which are major components of the global portfolio. Short rates are therefore not modelled explicitly, rather the monetary base in each region is determined as endogenous to the target of monetary policy and an exogenous parameter determines the share of any change in the monetary base that takes the form of long asset balance sheet expansion.
} 
"quantitative easing" components of monetary expansions by both home and foreign central banks.

\subsection{Global financial balance}

Financial balance then requires that total investment spending in region $i$, in i's local currency, is equated with the total supply of financing directed from all represented regions:

$$
I_{i}^{D}=\sum_{j}\left(\left[i_{j i}^{S} S_{j}^{D}+\theta_{j i}^{Q E} S_{j}^{Q E} \Delta M_{j}^{B}\right] \frac{E_{j}}{E_{i}}\right), \quad \forall i,
$$

Where $i_{j i}^{S}$ is the endogenous share of region $j$ 's domestic total (private and government) saving, $S_{j}^{D}$, that is directed to assets in region $i . E_{i}$ is the nominal exchange rate of region $i$ relative to the US\$. The "quantitative easing" share of the current period's expansion of the monetary base by region $j$ 's central bank, $s_{j}^{Q E}$, and the share of this expansion that takes the form of acquisitions of region $i$ 's long bonds, $\theta_{j i}^{Q E}$, both determine central bank demand. These flows are originally in foreign currency and are therefore converted at the appropriate cross rates. The regional real bond yields (interest rates, $r_{j}$ ) emerge from this equality. Their convergence across regions is larger the larger are the elasticities of asset substitution, $\sigma_{j}^{I}$.

The balance of payments condition requires that the sum of net inflows of payments on the current account and net inflows on the capital and financial accounts, measured in a single (home) currency is zero:

$$
X_{i}-M_{i}+\sum_{j \neq i}\left(\left[i_{j i}^{S} S_{j}^{D}+\theta_{j i}^{Q E} S_{j}^{Q E} \Delta M_{j}^{B}\right] \frac{E_{j}}{E_{i}}\right)-\sum_{j \neq i}\left(i_{i j}^{S} S_{i}^{D}+\theta_{i j}^{Q E} S_{i}^{Q E} \Delta M_{i}^{B}\right)=0, \quad \forall i \neq " U S^{\prime \prime}
$$

The first terms are nominal values of exports and imports while the second two terms are financial inflows and outflows. ${ }^{24}$ The first parenthesised term represents acquisitions of region i's home-issued long bonds by foreign savers and by foreign central banks, the latter associated, as above, with the "quantitative easing" component of the current period's expansions of the monetary bases across regions. These net saving and central bank flows are originally in foreign currency and so are converted at the appropriate cross rates. The second parenthesised term represents acquisitions of foreign-issued long bonds by region i's home savers and its own central bank. A balance of payments in the US is implied by balance in all

\footnotetext{
${ }^{24}$ Formulations of elements of the model not included here are provided in detail in the appendix to Tyers (2015a), and updated in the appendix to Tyers and Zhou (2018).
} 
the other regions. These equations determine the nominal exchange rates. Since these are defined relative to the US\$, that for the US is always unity $\left(E_{U S}=1\right)$, though nominal and real effective exchange rates are also calculated.

\subsection{Model database, parameters and operation}

The model database is built on national accounts as well as international trade and financial data for the global economy. ${ }^{25}$ The implications of changes in China for the three advanced regions are emphasised here and the scale of these economies, as represented in the database, is indicated in Table 1. Of particular interest here are the financial flows between these regions and the pattern of these is suggested in Table 2, from which it is important to note the comparatively substantial shares of the US and China in their respective financial inflows and outflows. $^{26}$

\section{Effects of the Growth Surge}

To quantify the internal and external effects of China's growth surge a set of model experiments is constructed. These require model closures, which indicate underlying assumptions about the labour market, fiscal policy, financial market clearance and monetary targeting, and a set of shocks that represent the drivers of the surge in its peak years. Two lengths of run are considered. The first is short, suggesting the effects within the year the shocks arise, and the second is long, allowing labour market clearance and capacity adjustments. They are detailed in Table $3 .{ }^{27}$ The growth surge shocks chosen are representative of empirical results centred on the Chinese economy in 2002-2007 to the extent that they indicate the underlying annual changes to productivity and factor endowments. They are listed in Table $4 .{ }^{28}$ The shock to the consumption equations captures the observed decline in the share of consumption expenditure and the rise in the share of private savings in GDP that was occurring in the period.

\footnotetext{
${ }^{25}$ We are using an updated version of our model in this analysis, with a database constructed from statistics for 2016. Since the Chinese economy was bigger relative to the rest of the world by then, compared with during the surge, the scale of the global spillovers may be overestimated. Our focus, however, is on financial integration counterfactuals and the proportional differences amongst these is not sensitive to the database year chosen.

${ }^{26}$ Further details as to the sources and construction of the database can be obtained from Tyers (2015a, Appendix 2) and updated in the appendix to Tyers and Zhou (2018).

${ }^{27}$ Keynesian and neoclassical assumptions about behavioural in responses to the Chinese shocks are compared using a similar model by Tyers (2015b). While there are key differences in financial market structure as between the two models, the contrasts that emerge are similar to those that would stem from the model used here.

${ }^{28}$ The capital accumulation and productivity shares of China's recent growth are controversial (Krugman 1994). The numbers used here are broadly consistent with the meta-analysis by $\mathrm{Wu}$ (2011).
} 
The numerical results for the default parameterisation of the model are summarised in Table 5. The surge, and the associated imbalance between production and consumption in China, created excess supply in the advanced economies and so would have been deflationary in the absence of money supply adjustment. The results shown indicate the size of monetary expansions needed in China and in the advanced economies to avoid contractionary deflations. These are between three and five per cent per year, which is considerably faster than the growth of the advanced economies at that time, yet still ignoring deflationary shocks other than those emanating from China. As expected, given the discussions in Section 2, the simulations confirm that the surge placed downward pressure on long interest rates globally. This suggests two alternative ways to think about the monetary expansions required to avoid deflation. On the one hand the excess supplies raised the relative abundance of goods relative to money and, on the other, the opportunity cost of money components in portfolios caused rebalancing in favour of liquidity, raising the demand for money relative to goods and thus reducing the prices of goods in terms of money. ${ }^{29}$

Real appreciations of the advanced currencies relative to China's, combined with consumption baskets that include imported products that are excluded from the calculation of producer or GDP prices, ensure that producer prices inflate relative to consumer prices. This stimulates employment in the short run and capital accumulation in the long run and drives moderate increases in real output in regions outside China. Associated moderate increases in the purchasing power of disposable incomes at domestic consumer prices (our measure of welfare) occur uniformly across the advanced regions. Meanwhile, in China, the effects are obviously much larger. Because China is assumed to maintain a de facto peg to the USD, the substantial real depreciations that arise from its productivity gains and its excess supply of goods cause large deflations, though these are insufficient to restrict employment in the short run or capital growth in the long run and very high rates of growth are achieved.

\section{Sensitivity to Type 2 Financial Integration}

Financial integration can be thought of in several ways, even within the confines of the model adopted here. The approach we use is to regard more financial integration as indicating more ready substitution of Chinese assets with those from all regions, reflected by a rise in China's elasticity of asset substitution, $\sigma_{i}^{I}$. Type 1 financial integration is endogenous in the simulations, occurring in response to shocks to Chinese consumption behaviour and to

\footnotetext{
${ }^{29}$ The use of UMP by Japan at the time of the surge also placed downward pressure on global long yields, though this effect is small in these simulations.
} 
endogenous reallocations of investment globally. What is added here is pure Type 2 financial integration, as defined in Section 3. It is here represented as the progression of China's $\sigma_{i}^{I}$ between two and 20, while holding the levels for the advanced economies at 20, representing high levels of financial integration. ${ }^{30}$ Here the analysis sets the values for the advanced economies as constant at 20 and examines the effects of allowing China's elasticity to rise from 2 to 20 .

For low values of $\sigma_{i}^{I}$, China's financial outflows are restricted to adhere to the original pattern of these flows reflected in the model's database (Table 2). As the values rise, the distribution of these outflows across regional assets is more responsive to relative yield changes. This includes greater flexibility of the share in China's collective portfolio of China's own domestic assets. To see the effect of this, the surge shocks are repeated for different values of this parameter. The effects of the shocks on regional bond yields, deflationary pressure, current account imbalance, real GDP and "welfare" (the real purchasing power of regional income at consumer prices) are assessed for the advanced regions.

More flexible Chinese portfolio management alters the effects of the growth surge, causing them to depart from the central values presented in Table 5. The proportions by which these results change, due to the full sweep of substitution elasticity values from 2 to 20 , are indicated in Table 6. Not surprisingly, given that the shocks are to the Chinese economy only, the Chinese performance indicators are the most strongly affected by some distance. Increased integration makes investment abroad easier. Since the surge caused a substantial rise in excess saving, the more readily that saving can escape abroad the smaller is its tendency to suppress Chinese home long bond yields. In the advanced regions, however, the arrival of additional Chinese saving in response to Type 2 integration ensures that long bond yields decline further than they otherwise would have. The expected movement toward convergence of bond yields between China and the advanced economies is evident from Figure 9, which suggests that full financial integration would cause a decline in yields in the advanced economies by about three per cent. At the rates in the database this suggests declines in 10 year bond yields of about 15 basis points. ${ }^{31}$ The proportional effects of financial integration on US yields are a bit larger since the initial flows from China to Europe and Japan are small relative to those destined for

\footnotetext{
${ }^{30}$ The values of the substitution elasticity of advanced regional assets used in generating the results in the previous section are less extreme than these ( 15 for the US and EU, 10 for Japan and 5 for China), representing other numerical measures of Type 2 financial integration (Tyers 2015a, Appendix 2).

${ }^{31}$ This is significant though small in relation to the changes in long yields due to excess saving by Japan and the petroleum exporters.
} 
the US. Even where proportional changes to initial shares of Chinese outflow to the EU and Japan are substantial, the small base tends to push most of the additional outflow to the US. Turning to the deflationary effects of the surge, the monetary expansions that are needed to maintain the targets of monetary policy in China and the advanced economies are indicated in Figure 10. Not surprisingly, the sizes of these expansions also depend on China's level of Type 2 financial integration. When this increases the deflationary pressure abroad also increases and, therefore, monetary expansions must be larger. This can be seen as driven by an increased presence of China's excess saving on global financial markets, suppressing yields and therefore opportunity costs of money holding, and so we observe portfolio rebalancing in favour of money. Increases in money demand then decrease the price levels of goods relative to money in foreign regions in the absence of supply expansions. In China, of course, the opposite is true. Its monetary target is its bilateral exchange rate with the US and expansions are needed to defend it, but these expansions are smaller the more financially integrated the economy. More financial integration implies smaller real depreciations against the advanced economies and smaller declines in domestic yields. Hence the rise in portfolio demand for home money within China is also smaller.

The scale of the deflations in the consumer price level that these monetary expansions are intended to avoid, and its sensitivity to financial integration, is indicated by Figure 11. Outside China these deflation forces are considerable - between one and two percentage points per year for the US and Japan - and they increase with greater financial integration. Indeed, for the US, the deflation pressure rises by almost a percentage point per year across the range of asset substitutability postulated. Similarly large effects occur on current account balances. Financial openness encourages more Chinese saving to go abroad, raising investment relative to domestic saving in foreign economies and so enlarging their current account deficits, as indicated in Figure 12. At the same time this reduces China's investment relative to its domestic saving and so drives its current account surplus higher. For the US, China's financial integration causes a current account deficit expansion of up to 0.1 per cent of GDP while China's surplus would rise by between 0.3 and 0.5 per cent of GDP.

The effects of financial integration on China's real GDP are to moderate its performance, as indicated in Figure 13. This is because greater integration causes more financial outflow from China, and hence less domestic investment, and with its fixed nominal exchange rate, more domestic deflation, which impairs employment in the short run and capital growth in the long run. China's real exchange rate depreciates more with greater integration, exacerbating the 
terms of trade shift against it. Even so, the net Chinese effects of the surge shocks remain substantially positive. Abroad, the US focus of China's outflows tends to mean that financial integration and the USD are positively correlated. With the consumer price level target of US monetary policy, this exchange rate appreciation narrows the gap between the consumer and producer prices and therefore raises producer prices the more integrated is the Chinese economy. The effect of this on employment and capital growth, and therefore real GDP, is positive but moderate. The net welfare effects by region are summarised in Figure 14. They show that Chinese welfare gains are smaller than those in real GDP, despite the deflation, due to growth in real wages that is slower than that in real GDP and that, as with real GDP, these gains diminish with financial integration.

Overall, the effects of the surge are quite sensitive to the level of China's financial integration. The Chinese effects are considerably moderated in the absence of controls restricting the rebalancing of its collective portfolio, including the growth surge itself. On the other hand, foreign effects are amplified by such integration, and particularly the deflationary pressures in the US.

\section{Conclusion}

The 2000s growth surge stimulated global growth but provided the first of several blows to the performance of global financial markets that culminated in the GFC and the high levels of investment uncertainty that persist today. Measures to quantify financial openness in China suggest that the surge occurred at a time when the economy was at its most open financially, based at least on Type 1 measures that depend only on domestic and foreign asset acquisitions and holdings. In terms of Type 2 measures, which account for restrictions on portfolio diversity, during the surge capital controls were strict and there was little formal integration. Changes in Type 2 measures did come later, as foreign holdings were increasingly allowed to diversify beyond official foreign reserves.

Here a global macroeconomic model with rebalancing national portfolios of containing international assets and explicit representation of unconventional monetary policy is used to both evaluate the international effects of these major changes in China and to assess, counterfactually, what the implications might have been had additional Type 2 financial integration been undertaken at the same time. This would have allowed Chinese portfolio managers more ready substitution of assets across investment destinations, reflected in the model by a rise in China's elasticity of asset substitution. It is shown that the economic effects 
on the advanced economies would have been larger the more these authorities might have allowed Type 2 integration. The surge itself was net beneficial to foreign economies but it suppressed global bond yields, imposed deflationary pressure offset by extraordinary, and ultimately unsustainable, monetary expansions and it caused current accounts to shift toward deficit. Such financial integration would have moderated the GDP and welfare gains accruing to the Chinese economy but it would have increased the effects on foreign economies. Net welfare gains would have been larger but the negative effects would have been larger, particularly the declines in global bond yields and the deflationary pressures in the US. Looking ahead, a reversal of China's external balance looms as it transitions to consumptionled growth and is faced with rising aged dependency (Golley et al. 2017), while at the same time the government seeks to sustain the level of investment. As the rate of overall growth slows the most efficient share of investment in GDP will necessarily fall, yet a political imperative is to sustain employment in what is the largest construction industry in the world. This could lead to further reforms in China, to the financial sector and in the protection of intellectual property rights of foreign investing firms. ${ }^{32}$ Deepening of Type 2 financial integration would then be necessary, as might be achieved through reduced controls on outward flows and the further expansion of global portfolio capital access through on shore bond and equity markets.

\footnotetext{
${ }^{32}$ The US-China trade conflict of 2018-9 is a reflection of this issue and its resolution is likely to embody reforms to foreign investment conditions (Tyers and Zhou 2019).
} 


\section{References}

Arora, V., R. Tyers and Y. Zhang (2014), "Reconstructing the savings glut: the global implications of Asian excess saving”, CAMA Working Paper No. 2014-02/20, Centre for Applied Macroeconomics, Australian National University, Canberra, February.

Autor, D.H., D. Dorn and G.H. Hanson (2013), "The China syndrome: local labor market effects of competition in the United States", American Economic Review, 103(6): 21212168.

Ballantyne, A., J. Hambur, I. Roberts and M. Wright (2014), "Financial reform in Australia and China," Reserve Bank of Australia Research Discussion Paper, RDP 2014-10, online available at

file://G:/material_curtin/Active\%20papers/financial\%20reform\%20paper/reading/1.pdf

Bayoumi, T., H. Tong, S.J. Wei (2010), “The Chinese corporate savings puzzle: a firm-level cross-country perspective", NBER Working Paper, No. 16423.

Bergsten, C.F., C. Freeman, N.R. Lardy and D.J. Mitchell (2008), China's Rise: Challenges and Opportunities, Washington DC: Peterson Institute for International Economics.

Berman, E., J. Bound and Z. Griliches (1994), "Changes in the demand for skilled labour within US manufacturing: evidence from the annual survey of manufactures", Quarterly Journal of Economics, 109(2): 367-397.

Bernanke, B.S. (2005), "Remarks by the Governor", Sandridge Lecture, Virginia Association of Economists, Richmond Virginia, March, Federal Reserve Board.

(2011), "Global imbalances: links to economic and financial stability", speech given at the Banque de France Financial Stability Review Launch Event, Paris, France February 18.

Blanchard. O. and F. Giavazzi (2006), "Rebalancing growth in China: a three-handed approach," China and the World Economy, Institute of World Economics and Politics, Chinese Academy of Social Sciences, 14(4): 1-20.

Bound, J. and G. Johnson (1992), "Changes in the structure of wages in the 1980s: an evaluation of alternative explanations", American Economic Review, 82(3): 371-392.

Borio, C. and P. Disyatat (2011), "Global imbalances and the financial crisis: link or no link", BIS Working Paper 346, Basel, May.

Bowles, P. (2012), "Rebalancing China's growth: some unsettled questions”, Canadian Journal of Development Studies, 33(1): 1-13.

Caballero, R.J. (2009), “The 'other' imbalance and the financial crisis", MIT Working Papers in Economics 9-32, Cambridge MA, December.

Caballero, R.J., E. Farhi and P.O. Gourinchas (2008), "An equilibrium model of 'global imbalances' and low interest rates", American Economic Review, 98(1): 358-393.

Chen, Q., A. Filardo, D. He, F. Zhu (2014), "Financial crisis, unconventional monetary policy and international spillovers", presentation at the ECB-IMF Conference on International Dimensions of Conventional and Unconventional Monetary Policy Frankfurt, April 2930.

Chinn, M.D., B. Eichengreen and H. Ito (2012), "Rebalancing global growth", in O. Canuto and D. Leipziger (eds), Ascent after Descent: Regrowing Economic Growth after the Great Recession, Washington DC: World Bank: 35-86.

Chinn, M.D. and H. Ito (2007), "Current account balances, financial development and institutions: assaying the world 'saving glut'", Journal of International Money and Finance, 26: 546-569.

Choi, H., N.C. Mark and D. Sul (2008), "Endogenous discounting, the world saving glut and the US current account", Journal of International Economics, 75: 30-53. 
Di Giovanni, J., A.A. Levchenko and J. Zhang (2013), "Global welfare effect of China: trade integration and technical change", American Economic Journal: Macroeconomics, 6(3): 153-183.

Eichengreen, B. (2004), "Global Imbalances and the Lessons of Bretton Woods," NBER Working Paper 10497, Cambridge Mass: National Bureau of Economic Research.

Eickmeier, S. and M. Kuehnlenz (2018), "China's role in global inflation dynamics", Macroeconomic Dynamics, Cambridge University Press, 22(02): 225-254, March.

Feldstein, M. and C.Y. Horioka (1980), "Domestic Saving and International Capital Flows," Economic Journal, Royal Economic Society, 90(358): 314-29, June.

Feng, C. and L. Yang (2013), "The end of China's demographic dividend", Ch.4 in R. Garnaut, C. Fang and L. Song (eds), China: a New Model for Growth and Development, Canberra: ANU E Press and Beijing: Social Sciences Academic Press: 55-74.

Fernández, A., M.W. Klein, A. Rebucci, M. Schindler and M. Uribe (2016), "Capital Control Measures: A New Dataset", IMF Economic Review, 64(3): 548-574.

Francois, J.F. and D. Nelson (1998), "Trade, technology and wages: general equilibrium mechanics," Economic Journal, 108: 1483-99.

Francois, J.F. and G. Wignaraja (2008), "Economic implications of Asian integration," Global Economy Journal, 8 (3): 1-48, September.

Garcia-Herrero, A. (2015), "Internationalizing the currency while leveraging massively: the case of China", Bruegel Working Paper, 2015/12.

Garner, J. and H. Qiao (2013), "China - household consumption most likely US1.6 trillion larger than officially stated”, Asian Insight, Morgan Stanley Research, 28 February 2013, http://www.morganstanleychina.com/views/121217.html.

Genberg, H. and W. Zhang (2010), "Can China save the world by consuming more?" VOX EU, 25 April.

Golley, J., R. Tyers, and Y. Zhou (2017), "Fertility and savings contractions in China: Long run global implications", The World Economy, 41(11): 3194-3220.

Harris, R.G. and P.E. Robertson (2013), "Trade, wages and skill accumulation in the emerging giants", Journal of International Economics, 89(2): 407-421, March.

Harris, R.G, P.E. Robertson and J. Xu (2011), "The international effects of China's trade and education booms", The World Economy, 34(10): 1703-1725.

Haskel, J., R.Z. Lawrence, E.E. Leamer and M.J. Slaughter (2012), "Globalization and U.S. Wages: Modifying Classic Theory to Explain Recent Facts," Journal of Economic Perspectives, American Economic Association, 26(2): 119-40, Spring.

He, D. and R.N. McCauley (2013), "Transmitting global liquidity to East Asia: policy rates, bond yields, currencies and dollar credit", Hong Kong Institute for Monetary Research Working Paper No.15/2013, BIS Working Papers 431, Bank for International Settlements, October.

He, D., L. Cheung, W. Zhang and T. Wu (2012), "How would capital account liberalization affect China's capital flows and renminbi real exchange rates?" China and the World Economy, 20(6): 29-54, November.

Helpman, E., O. Itskhoki and S.J. Redding (2010), "Inequality and Unemployment in a Global Economy," Econometrica, 78(4): 1239-83.

Ho, N.W. (2009), "Financial Integration: Concepts and Impacts," Macao Monetary Research Bulletin, 10: 69-84.

Hsieh, C.T. and P. Klenow (2009), "Misallocation and manufacturing TFP in China and India", Quarterly Journal of Economics, 124: 1403-1448, November.

Huang, Y. and X. Wang (2018), “'Strong on quantity, weak on quality': China's financial reform between 1978 and 2018”, in Garnaut, R., Song, L. and Cai, F. (eds.), China's 40 years of reform and development: 1978-2018, ANU Press. 
Huang, Y., J. Chang and L. Yang (2012), "Consumption recovery and economic rebalancing in China", prepared for the Asian Economic Panel, March 22-23, Seoul, Korea, published in Asian Economic Papers, 12(1): 47-67, Winter/Spring 2013.

Huang, Y., X. Wang, B. Wang and N. Lin (2010), "Financial Reform in China: Progresses and Challenges", PAFTAD Conference Paper, online available a http://www.paftad.org/files/34/07 HUANG Fin\%20Reform nofig.pdf

Ito, H. (2009), "US current account debate with Japan then, and China now", Journal of Asian Economics, 20: 294-313. (2013), "Monetary policy in Asia and the Pacific in the post, post-crisis era", presented at the 36th Pacific Trade and Development (PAFTAD) Conference, "Financial Development and Cooperation in Asia and the Pacific," Hong Kong Monetary Authority, November 19-21, 2013.

Johnson, R.S., R.A. Zuber and J.M. Gandar (2010), “A re-examination of the market segmentation theory as a pedagogical model", Journal of Financial Education, 36(1/2): $1-37$, Spring/Summer.

Kanbur, R. and X. Zhang (2005), "Fifty years of regional inequality in China: a journey through revolution, reform and openness," Review of Development Economics, 9(1):87106.

Kuznets, S. (1955), "Economic growth and income inequality," American Economic Review, 45 (1): 1-28.

Krugman, P. (1994), “The myth of Asia's miracle”, Foreign Affairs, 73(6): 62-78, Nov-Dec. (1995), "Growing world trade: causes and consequences", Brookings Papers, 1: 327377. (2010) "Capital export, elasticity pessimism and the renminbi (wonkish)", New York Times (blog), 16 March.

Lardy, N.R. (2006), 'Toward a consumption-driven growth path”, Policy Brief, 06-6, Washington DC: Peterson Institute for International Economics.

Lardy, N.R. (2012), Sustaining China's Growth after the Global Financial Crisis, Washington DC: Peterson Institute for International Economics, January.

Leamer, E.E (1996), "Wage inequality from international competition and technological change: theory and country experience", American Economic Review, American Economic Association, 86(2): 309-14, May.

Lee, J.W. and W.J. McKibbin (2007), "Domestic investment and external imbalances in East Asia”, CAMA Working Paper 4-2007, Canberra: Australian National University.

Levchenko, A.A. and J. Zhang (2012), "The global labor market impact of emerging giants: a quantitative assessment", paper presented at the 13th Jacques Polak Annual Research Conference, hosted by the IMF, Washington DC, November 8-9.

Lien, D. and Z. Zhang (2018), "IntroductiontoChina'sriseand financial marketintegration in East Asia: Issues and prospects", Editorial, North American Journal of Economics and Finance, in press.

Lim, R.E. (2017), "Reviewing recent developments in China's capital markets and assessing the relevance of the Proposed Shanghai International Board", Capital Markets Law Journal, 12(1): 78-93.

Ma. G., I. Roberts, and G. Kelly (2018), "China's economic rebalancing: Drivers, outlook and the role of reform", in Garnaut, R., Song, L. and Cai, F. (eds.), China's 40 years of reform and development: 1978-2018, ANU Press.

Ma. G, R. McCauley and L. Lam (2013), "The roles of saving, investment and the Renminbi in rebalancing the Chinese economy", Review of International Economics, 21(1):72-84.

Ma, G. and R.N. Mccauley (2014), "Financial openness of China and India: Implication for capital account openness", Bruegel Working Paper, 2014/05. 
Ma, G. and W. Yi (2010), “China's high saving rate: myth and reality”, International Economics, 122: 5-40.

Naughton, B. (2017), “Is China Socialist?" Journal of Economic Perspectives, 31(1): 3-24.

N'Daiye, P., P. Zhang and W. Zhang (2010), "Structural reform, intra-regional trade, and medium-term growth prospects of East Asia and the Pacific - perspectives from a new multi-region model", Journal of Asian Economics, 21: 20-36.

Rey, H. (2013), "Dilemma not trilemma: the global financial cycle and monetary policy independence", Federal Reserve Bank of Kansas City Economic Symposium at Jackson Hole, August.

Rodrik, D. (2016), "Premature deindustrialization", Journal of Economic Growth, 21(1): 1-33, March.

(2017), "Populism and the economics of globalization", NBER Working Paper 23559, Cambridge MA.

Rogoff, K. (2013), "Inflation is still the lesser evil", Project Syndicate, 6 June 2013, http://www.project-syndicate.org/commentary/, accessed 12 June 2013.

Shiller, R. J., J.Y. Campbell and K.L. Schoenholtz (1983), "Forward rates and future policy: interpreting the term structure of interest rates", Brookings Papers on Economic Activity, 1983(1): 173-223.

Shin, H.S. (2011), "Global Banking Glut and Loan Risk Premium”, Presented at the 12th Jacques Polak Annual Research Conference Hosted by the International Monetary Fund, Washington, DC, November 10-11.

Song, L., J. Yang and Y. Zhang (2011), "State-owned enterprises' outward investment and the structural reform in China", China and the World Economy, 19(4): 38-53.

Song, Z., K. Storesletten, and F. Zilibotti (2011), "Growing like China," American Economic Review, 101:202-241.

Sun, S. (2009), "How does FDI affect domestic firms' exports? Industrial evidence", $\underline{\text { How does }}$ FDI affect domestic firms' exports? Industrial evidence, 32(8): 1203-1222.

Tung, C.Y., G.C. Wang and J. Yeh (2012), "Renminbi internationalization: Progress, prospect and comparison", China \& World Economy, 20(5): 63-82.

Tyers, R. (2014), "Looking inward for transformative growth", China Economic Review, 29: $166-184$.

(2015a), "Pessimism shocks in a model of global macroeconomic interdependence", International Journal of Economics and Finance, 7(1): 37-59, January.

Tyers, R. (2015b), "International effects of China's rise and transition: neoclassical and Keynesian perspectives," Journal of Asian Economics, 37: 1-19, April.

Tyers, R. and Y. Yang (1997), "Trade with Asia and skill upgrading: effects on labor markets in the older industrial countries", Review of World Economics, 133(3): 383-418, September. (2000). "Capital-Skill Complementarity and Wage Outcomes Following Technical Change in a Global Model", Oxford Review of Economic Policy 16: 23-41.

Tyers, R. and Y. Zhang (2011), "Appreciating the renminbi", The World Economy, 34(2): 265297, February. (2014), "Real exchange rate determination and the China puzzle", $\underline{\text { Asian-Pacific }}$ Economic Literature, 28(2): 1-32, November.

Tyers, R. and Y. Yang (1997), "Trade with Asia and skill upgrading: effects on labor markets in the older industrial countries", Review of World Economics, 133(3): 383-418, September. (2000). "Capital-Skill Complementarity and Wage Outcomes Following Technical Change in a Global Model", Oxford Review of Economic Policy, 16: 23-41. 
Tyers, R. and Y. Zhang (2011), “Appreciating the renminbi", The World Economy, 34(2): 265297, February.

Tyers, R. and Y. Zhou (2018), "Deflation forces and inequality”, CAMA Working Paper 15/2018, Australian National University, April. (2019), “The US-China trade dispute: a macro perspective", Discussion Papers in Economics, UWA Business School.

Wicksell, K. (1898), Interest and prices: a study of the causes regulating the value of money, Translation from German, London: Macmillan, 1936.

Winchester, N. and D. Greenaway (2007), "Rising wage inequality and capital-skill complementarity," Journal of Policy Modeling, 29(1): 41-54.

Wood, A. (2018), "The 1990s trade and wages debate in retrospect", The World Economy, 41(4): 975-999.

Wood, A. (1994), North-South Trade, Employment and Inequality, Oxford: Clarendon Press.

World Bank (2013), Capital for the Future: Saving and Investment in an Interdependent World, Washington DC, 147 pp.

$\mathrm{Wu}, \mathrm{Y}$. (2011), "Total factor productivity growth in China: a review", Journal of Chinese Economic and Business Studies, 9(2): 111-126.

Yang, D.T. (2012), "Aggregate savings and external imbalances in China”, Journal of Economic Perspectives, 26, 4, 125-146. 
Figure 1: Official real GDP growth of China, annual percent change, 1980-2018

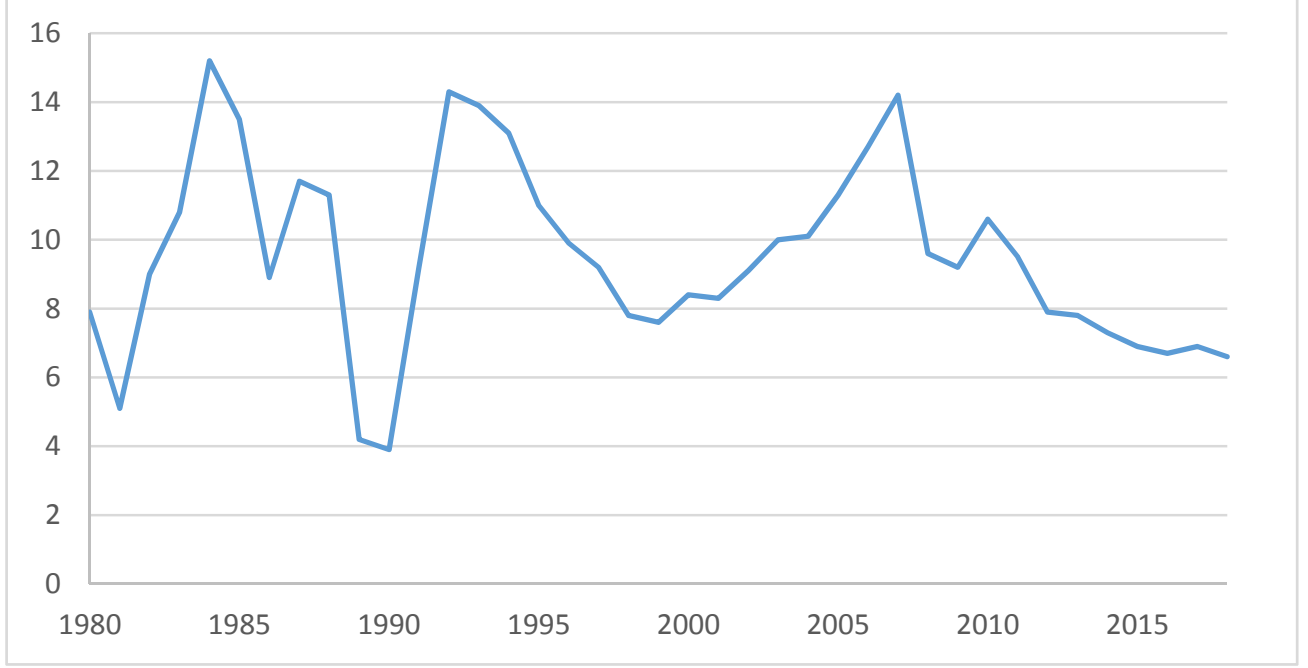

Source: IMF World Economic Outlook.

Figure 2: Long Term Bond Yields in Advanced Economies

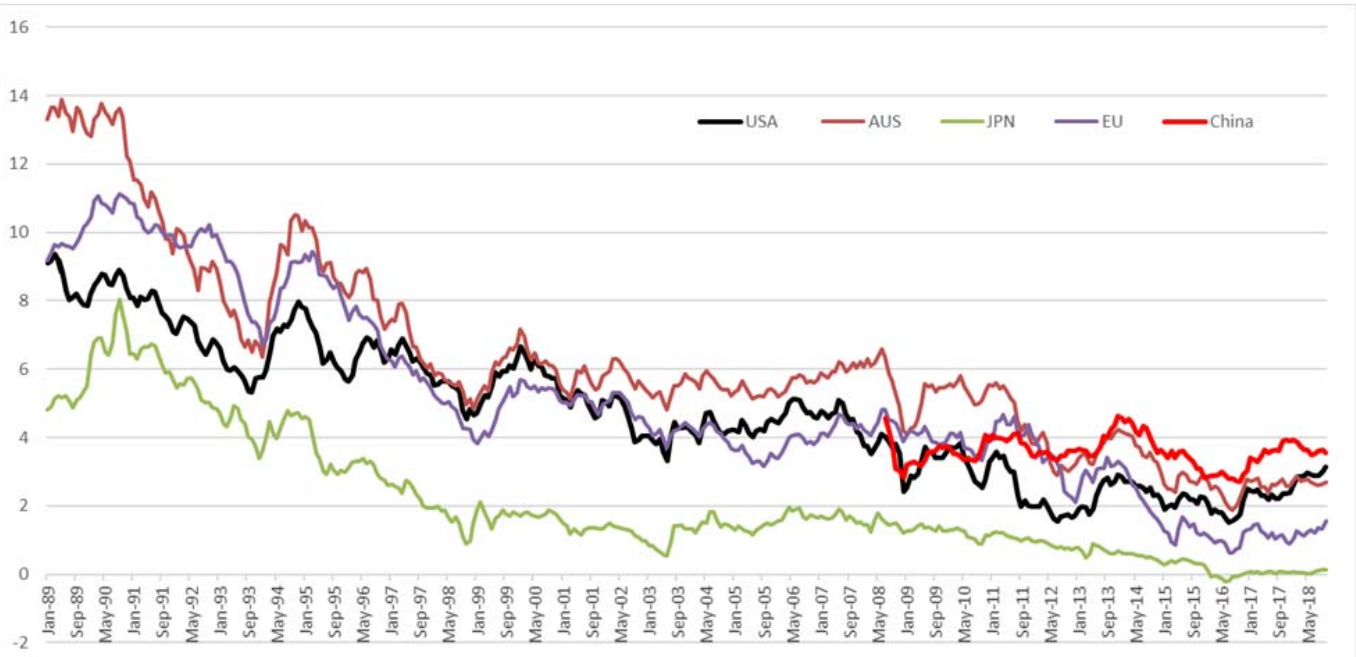

Sources: Long-term interest rates refer to government bonds maturing in ten years. Long-term interest rates in this figure are monthly averages of daily rates, measured as a percentage. Rates for USA, Australia, and Japan are obtained from the OECD Database. Rates for EU and China are obtained from the CEIC Database. 
Figure 3: Saving, investment and external balance of the Chinese economy (1987-2017)

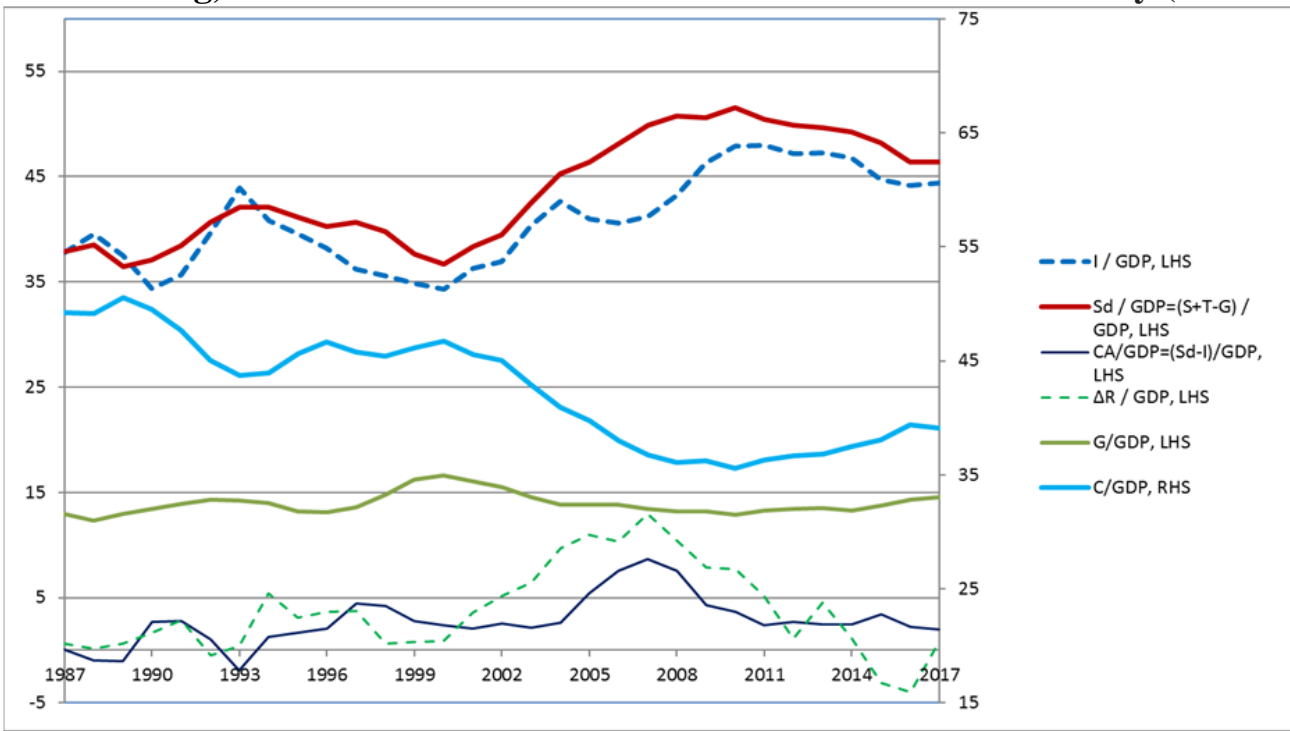

Source: Authors' calculations based on data from the CEIC Database and State Administration of Foreign Exchange (SAFE). Data on current account and change of official reserve are obtained from SAFE. Other data are obtained from the CEIC Database.

Figure 4: FDI inflow and its share of total domestic investment in China (\%)

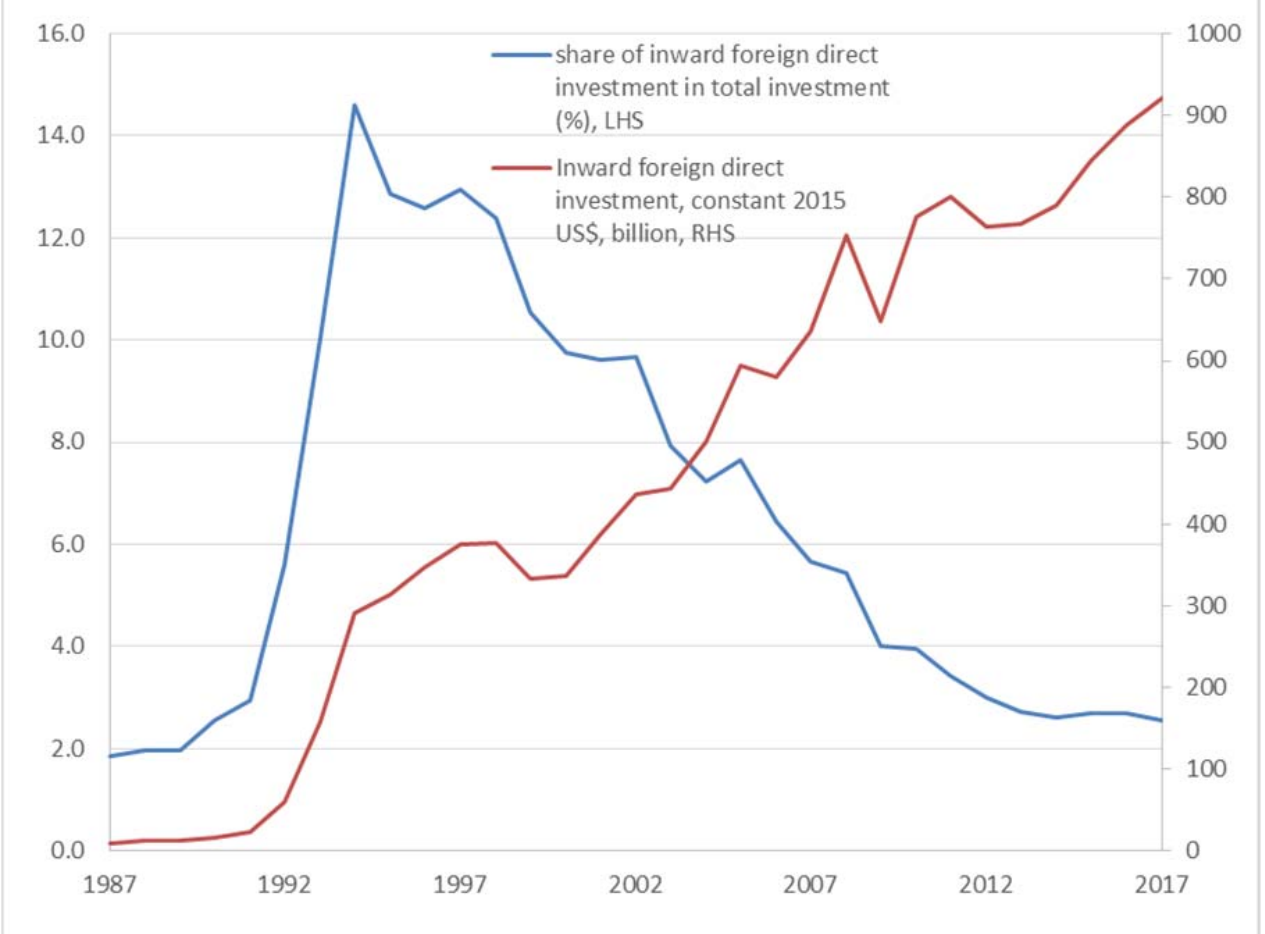

Source: Authors' calculations based on data from United Nations Conference on Trade and Development (UNCTAD) and the CEIC Database. From UNCTAD, data for inward foreign direct investment as share of GDP in China are obtained. Based on data in the CEIC Database, we calculate total domestic investment as a share of GDP in China. We then calculate the share of FDI inflow in total domestic investment by dividing the former by the latter. For the red series real GDP is calculated in constant 2015 US\$ based on the IMF World Economic Outlook Database. Then this is multiplied by the share of inward FDI in GDP to obtain inward FDI in constant 2015 US\$. 
Figure 5: Net investment inflow, billion USD (1982-2017)

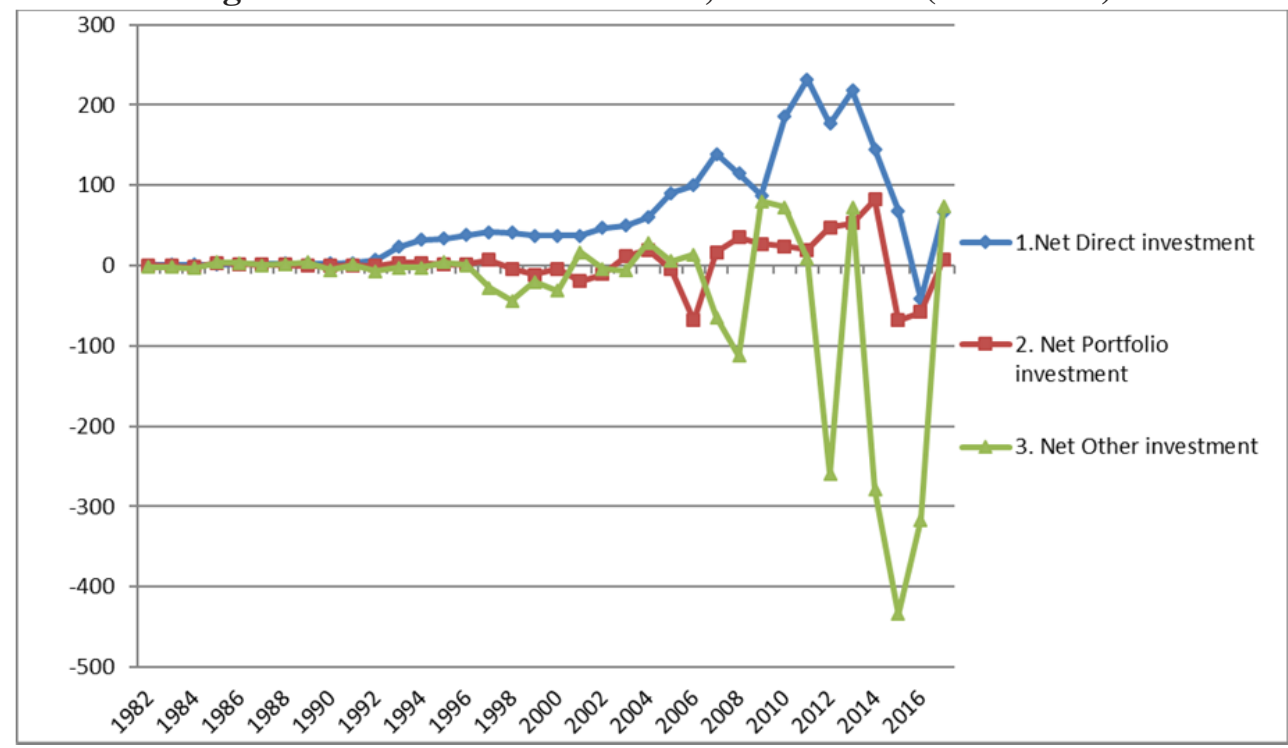

Source: Authors' calculations based on data on total credits and total debits of direct investment, portfolio investment and "other investment" in "The Balance of Payments Table" from China's State Administration of Foreign Exchange (SAFE). Net investment of each type of asset is the difference between total credits and total debits of each type of asset.

Figure 6: Gross balance of payments flows, China, \% of GDP (1982-2017)

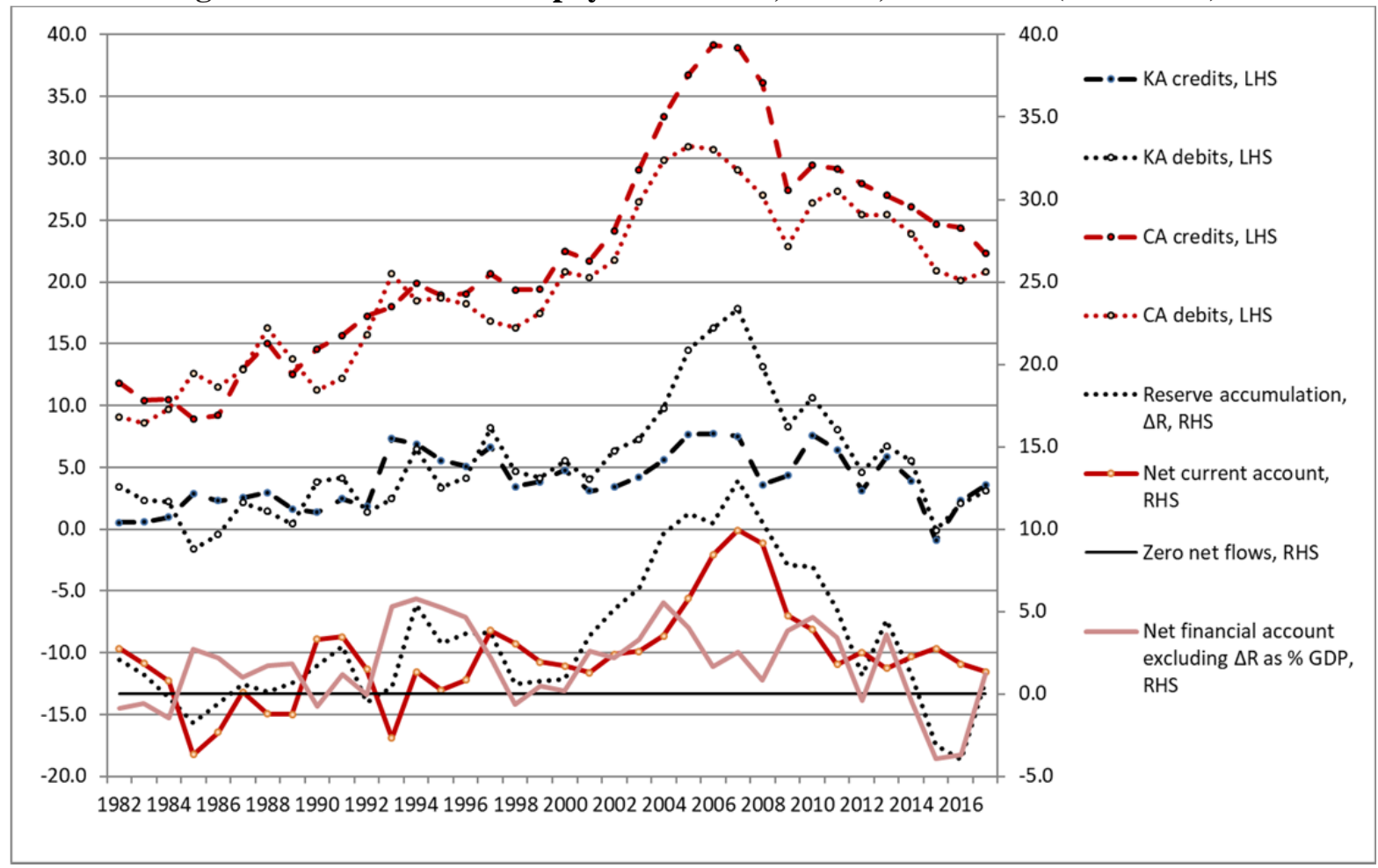

Source: Authors' calculations based on data from "The Balance of Payments Table" from China's State Administration of Foreign Exchange (SAFE) and the CEIC Database. Data for the financial and capital accounts (consolidated here and referred to as "KA"), the current account, and the change of official foreign reserves are obtained from SAFE, and data for GDP are obtained from the CEIC Database. 
Figure 7: De facto measures of China's Type 1 financial openness

(First five relate to stocks of foreign assets and liabilities; the sixth depends on flows)



Source: Authors' calculations based on data from State Administration of Foreign Exchange (SAFE). SAFE provides data on China's International Investment Position on an annual basis. These data cover foreign assets, foreign liabilities, and their detailed components direct investment assets, direct investment liabilities, portfolio investment assets, portfolio investment liabilities, other investment assets, other investment liabilities, and reserve assets as shares of GDP. The bottom right index is constructed based on Paranavithana et al. (2018). The index depends in every period on the ratio of gross capital outflows (debits on the capital and financial accounts) to total domestic savings $\left(S_{d}\right)$ on the one hand and that of the gross value of financial capital inflows (credits on the capital and financial accounts) to the level of gross domestic investment (I): Financial capital openness index $=$ $\frac{1}{2}\left[\frac{\mid K A \text { debits } \mid}{\left|S_{d}\right|}+\frac{\mid K A \text { credits } \mid}{|I|}\right]$. When the value of gross capital inflows is close to the value of total domestic investments and the value of gross capital outflows is close to the total domestic savings, the average value of the financial capital openness index tends towards unity. The most extreme case would be where gross capital outflows represent very low values compared to total domestic savings and gross capital inflows represent very low values compared to total domestic investment expenditure. This occurs if non-resident and resident flows are controlled, in which case the financial openness index is near zero. 
Figure 8: De jure measures of Chinese financial integration

Chin-Ito Index of financial openness, 1984-2016

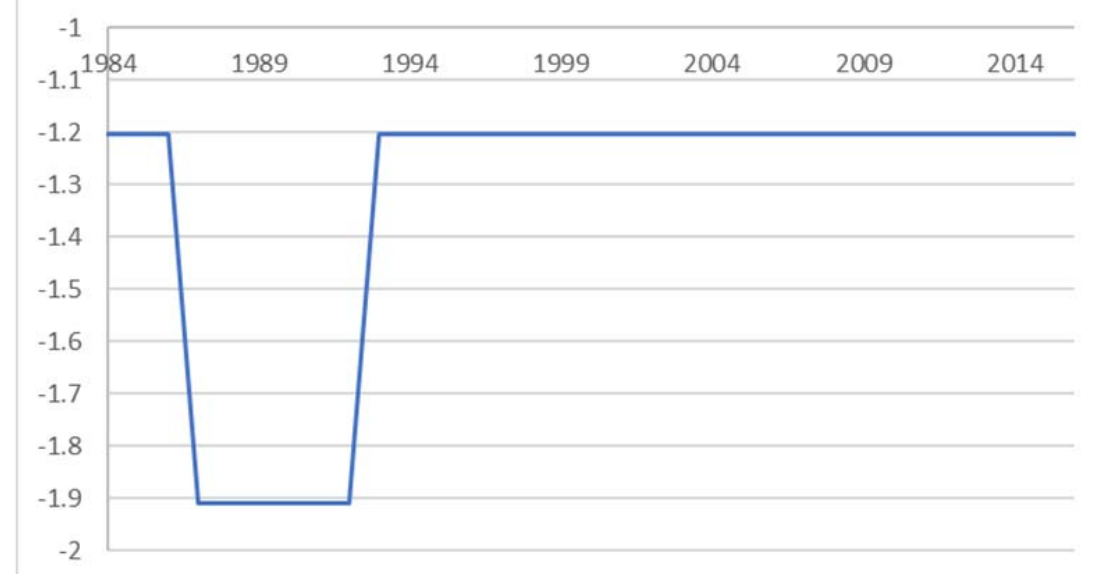

Source: Chin and Ito (2006). The index is update to 2016 and is available from the Chin-Ito Index Website at http://web.pdx.edu/ ito/Chinn-Ito website.htm. As is explained with details in Chinn and Ito (2006), the Chin-Ito Index is the first principal component of the original variables pertaining to regulatory controls over current or capital account transactions, the existence of multiple exchange rates, and the requirements of surrendering export proceeds in the Annual Report on Exchange Arrangements and Exchange Restrictions (AREAER) published by the International Monetary Fund. This index takes on higher values the more open the country is to cross-border capital transactions. By construction, the series has a mean of zero.

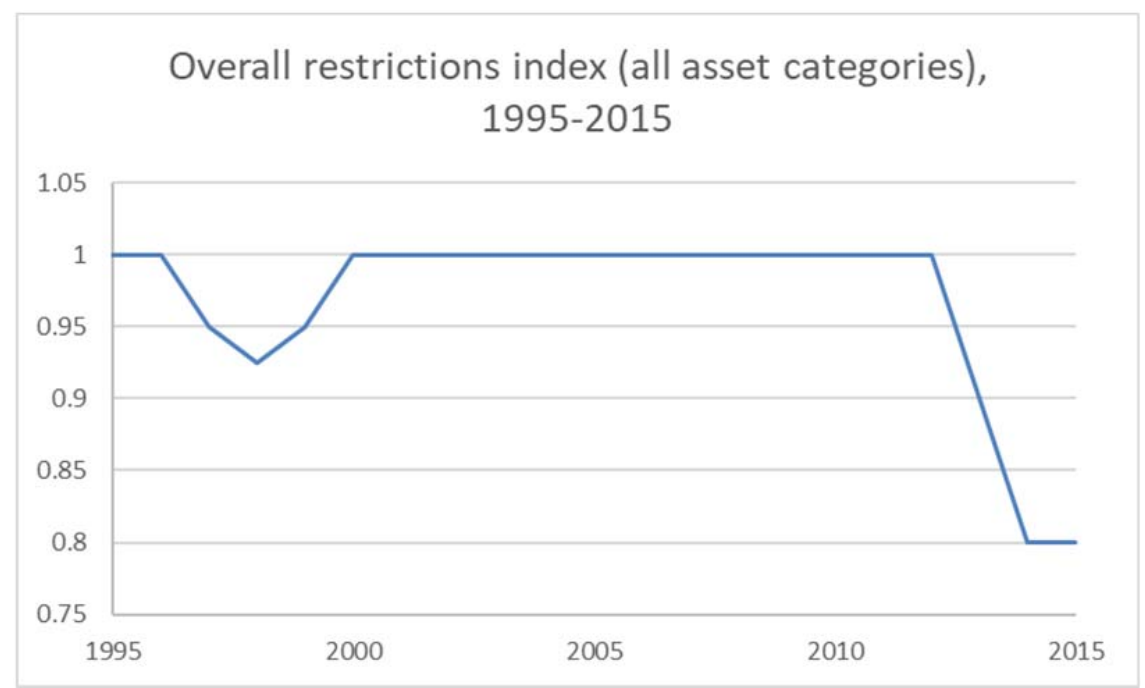

Source: Fernández et al. (2016). The index is normalized to [0,1], with higher values indicating higher restrictiveness. This index is a measures of de jure restrictions on cross-border financial transactions. It differs from Chin-Ito Index in terms of the way information is extracted from the Annual Report on Exchange Arrangements and Exchange Restrictions (AREAER) published by the International Monetary Fund. 
Figure 9: Growth Surge Effects on Long Yields with Varying Financial Integration ${ }^{\mathrm{a}, \mathrm{b}}$ (per cent changes in regional long bond yields)

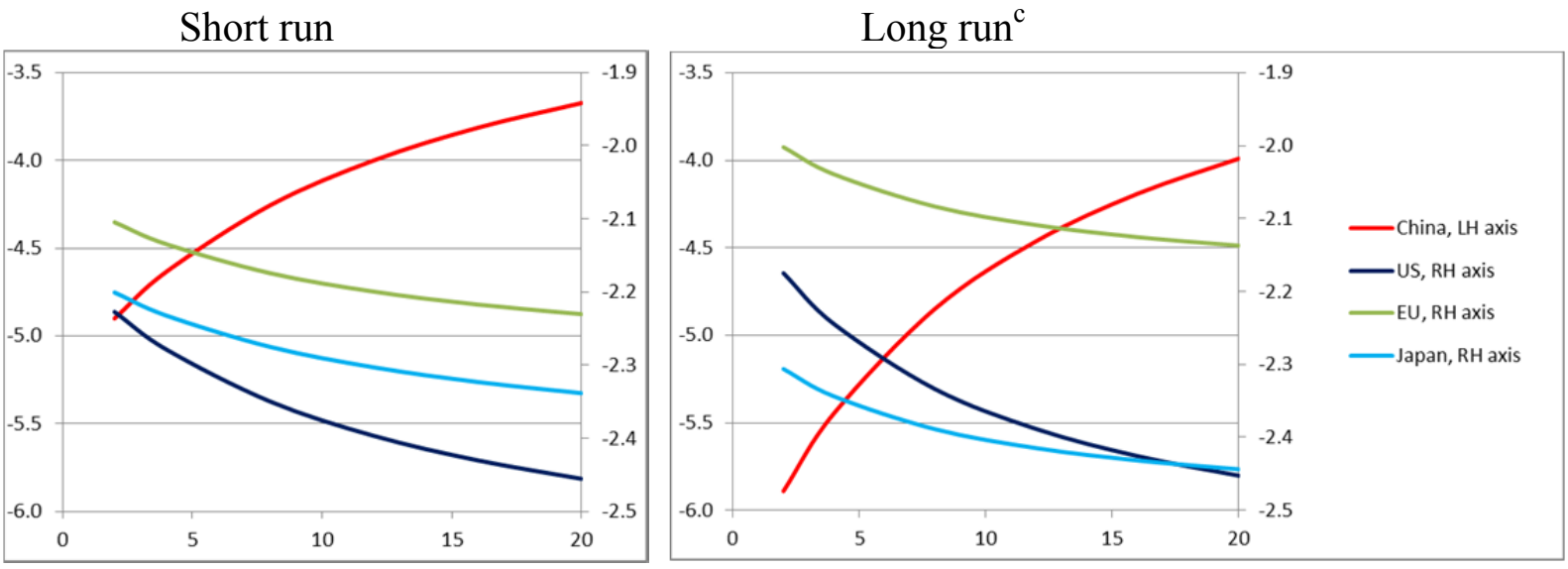

a The horizontal axis is the elasticity of substitution between Chinese and other global assets, $\sigma^{I}$.

$\mathrm{b}$ The simulations approximate the effects of a single year's change to the Chinese economy at the peak of its growth surge.

c The long run simulations maintain constant employment while allowing financial flows to deliver changes in capital stocks and hence adjustments in production capacity. Fiscal balance is maintained by adjusting tax rates on consumption expenditure.

Source: Simulations of the model described in the text.

\section{Figure 10: Growth Surge Effects on Required Monetary Expansions with Varying Financial Integration ${ }^{\text {a,b,c }}$}

(per cent changes in regional money supplies)

Short run

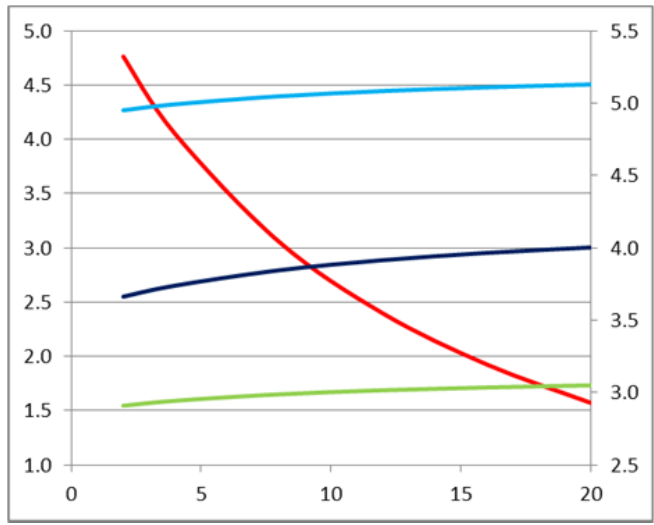

Long run ${ }^{\mathrm{d}}$

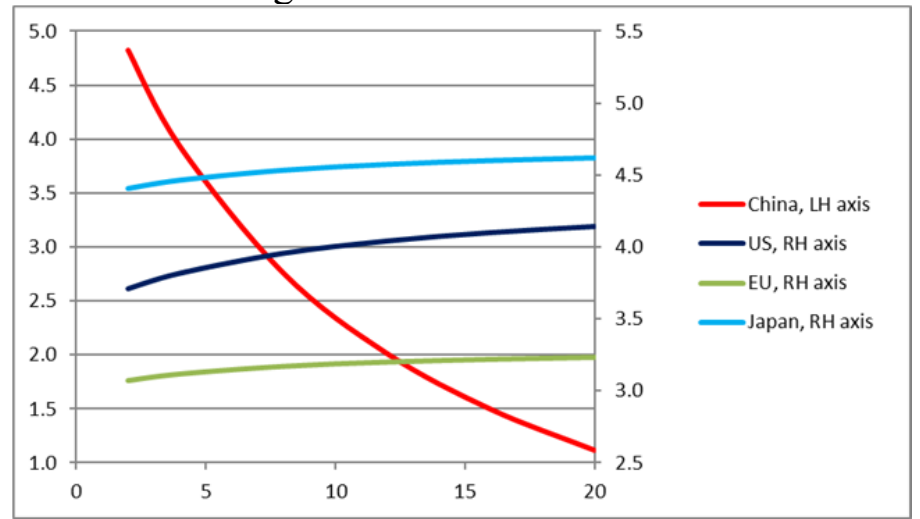

a The horizontal axis is the elasticity of substitution between Chinese and other global assets, $\sigma^{I}$.

$\mathrm{b}$ The simulations approximate the effects of a single year's change to the Chinese economy at the peak of its growth surge.

c The targets of monetary policy in the advanced economies are set at zero consumer price inflation, while in China and the rest of the world it is the US\$ exchange rate.

$\mathrm{d}$ The long run simulations maintain constant employment while allowing financial flows to deliver changes in capital stocks and hence adjustments in production capacity. Fiscal balance is maintained by adjusting tax rates on consumption expenditure.

Source: Simulations of the model described in the text. 


\section{Figure 11: Growth Surge Effects on Consumer Price Levels that would Occur in the Absence of Monetary Expansions, with Varying Financial Integration ${ }^{\text {a,b,c }}$}

(per cent changes in consumer price levels)
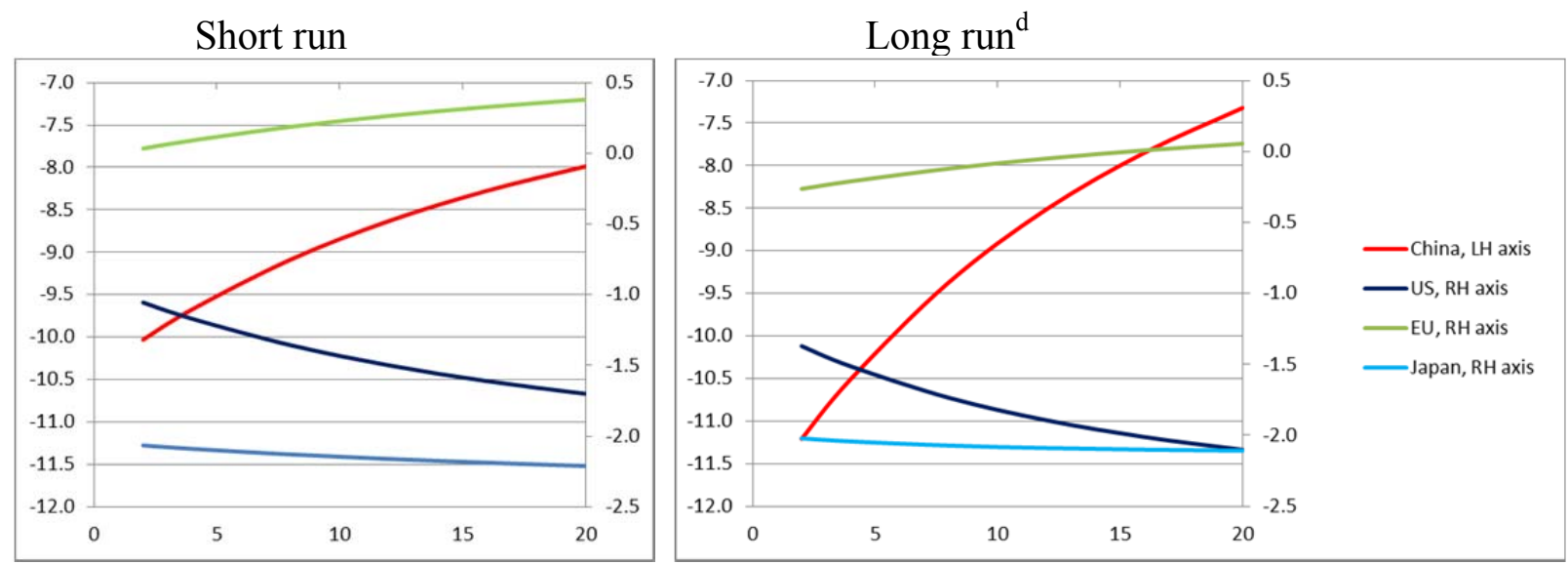

a The horizontal axis is the elasticity of substitution between Chinese and other global assets, $\sigma^{I}$.

b The simulations approximate the effects of a single year's change to the Chinese economy at the peak of its growth surge.

c Here the targets of monetary policy are simply set to zero money supply growth in all regions.

$\mathrm{d}$ The long run simulations maintain constant employment while allowing financial flows to deliver changes in capital stocks and hence adjustments in production capacity. Fiscal balance is maintained by adjusting tax rates on consumption expenditure.

Source: Simulations of the model described in the text.

\section{Figure 12: Growth Surge Effects on Current Account Balances, with Varying Financial Integration $^{\mathrm{a}, \mathrm{b}}$}

(changes in current account balances in percentage points of GDP)

Short run ${ }^{\mathrm{d}}$

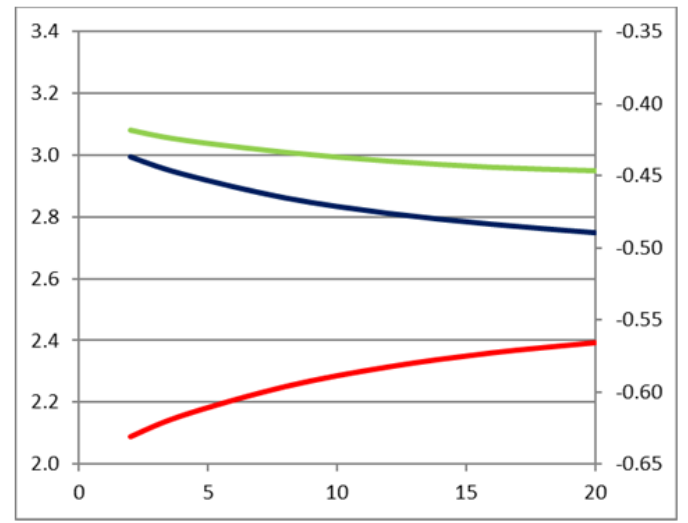

Long run ${ }^{\mathrm{c}}$

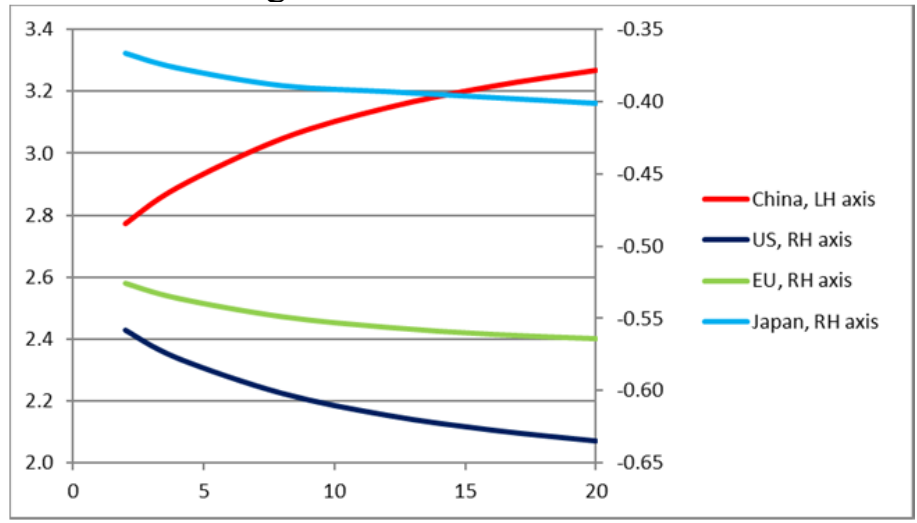

a The horizontal axis is the elasticity of substitution between Chinese and other global assets, $\sigma^{I}$.

$\mathrm{b}$ The simulations approximate the effects of a single year's change to the Chinese economy at the peak of its growth surge.

c The long run simulations maintain constant employment while allowing financial flows to deliver changes in capital stocks and hence adjustments in production capacity. Fiscal balance is maintained by adjusting tax rates on consumption expenditure.

$\mathrm{d}$ The results in the short run for the US and Japan are near coincidental and so those for Japan are not distinguished.

Source: Simulations of the model described in the text. 
Figure 13: Growth Surge Effects on Real GDP, with Varying Financial Integration ${ }^{\text {a,b }}$ (per cent changes real GDP)
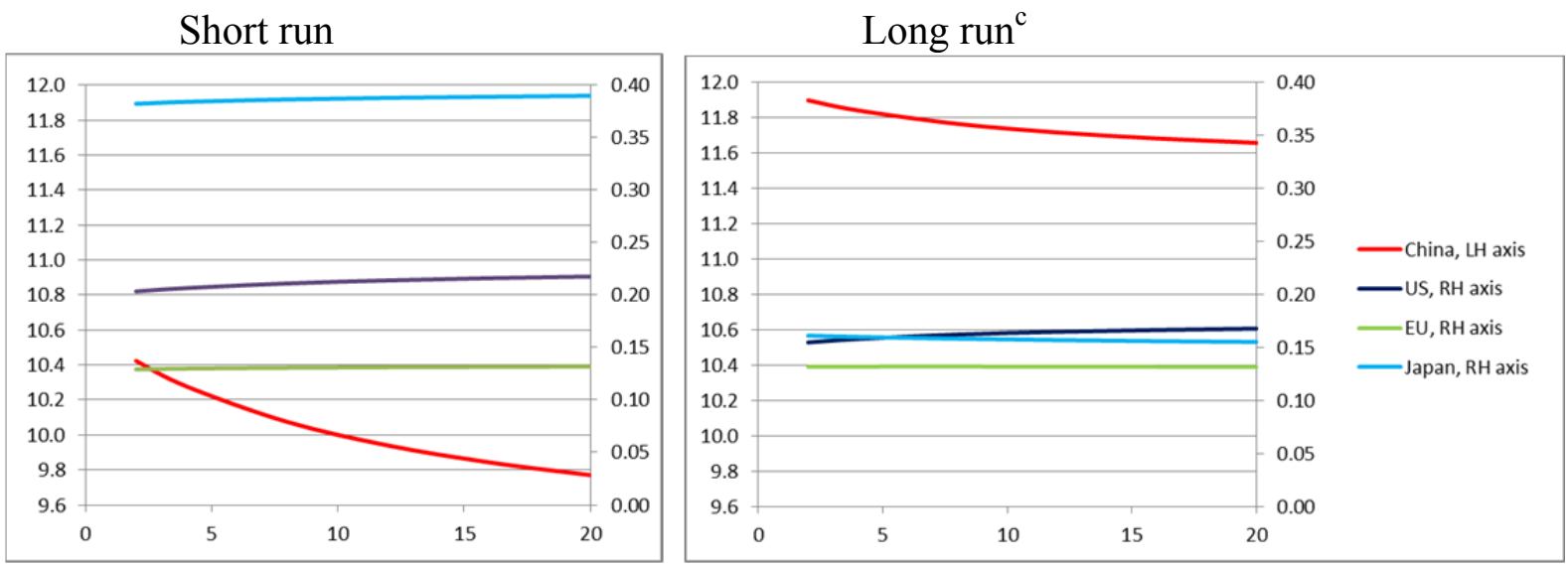

a The horizontal axis is the elasticity of substitution between Chinese and other global assets, $\sigma^{I}$. $\mathrm{b}$ The simulations approximate the effects of a single year's change to the Chinese economy at the peak of its growth surge.

c The long run simulations maintain constant employment while allowing financial flows to deliver changes in capital stocks and hence adjustments in production capacity. Fiscal balance is maintained by adjusting tax rates on consumption expenditure.

Source: Simulations of the model described in the text.

\section{Figure 14: Growth Surge Effects on Economic Welfare, with Varying Financial Integration $^{\mathrm{a}, \mathrm{b}}$}

(per cent changes in the real purchasing power of disposable income at consumer prices)
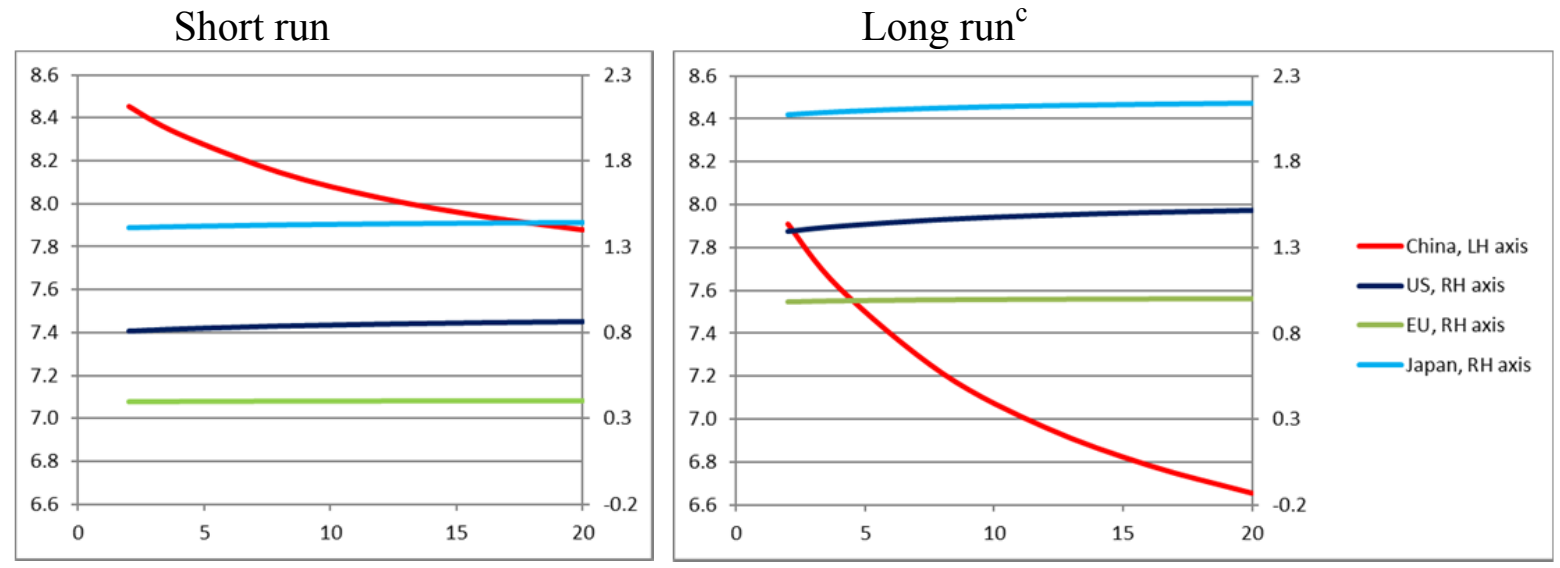

a The horizontal axis is the elasticity of substitution between Chinese and other global assets, $\sigma^{I}$.

$\mathrm{b}$ The simulations approximate the effects of a single year's change to the Chinese economy at the peak of its growth surge.

c The long run simulations maintain constant employment while allowing financial flows to deliver changes in capital stocks and hence adjustments in production capacity. Fiscal balance is maintained by adjusting tax rates on consumption expenditure.

Source: Simulations of the model described in the text. 
Table 1: Relative Economic Sizes of China and the Other Large Regions, ca 2016

\begin{tabular}{lllll}
\hline \multicolumn{1}{c}{$\%$ of world } & China & US & EU(26) & Japan \\
\hline GDP & 15 & 25 & 22 & 7 \\
Consumption, $C$ & 10 & 30 & 22 & 7 \\
Investment, $I$ & 27 & 19 & 17 & 6 \\
Government spending, $G$ & 12 & 23 & 27 & 7 \\
Exports, $X$ & 17 & 17 & 24 & 7 \\
Imports, $M$ & 15 & 21 & 23 & 8 \\
Total domestic saving, $S^{D}$ & 27 & 16 & 18 & 6 \\
\hline
\end{tabular}

Sources: National accounts data supply most of the elements though adjustments have been required to ensure that current accounts sum to zero globally, as do capital/financial accounts. The IMF-IFS database is the major source but there is frequent resort to national statistical databases.

Table 2: Shares of Total Domestic Saving Directed to Investment in each Region, 2016

\begin{tabular}{|c|c|c|c|c|c|c|}
\hline $\begin{array}{l}\% \text { of row total } \\
\text { saving }\end{array}$ & US & $\mathrm{EU}(28)$ & Japan & China & Australia & RoW \\
\hline $\mathrm{US}^{\mathrm{b}}$ & 68.0 & 13.3 & 6.4 & 6.4 & 1.5 & 4.4 \\
\hline $\operatorname{EU}(26)^{\mathrm{c}}$ & 12.9 & 80.1 & 2.3 & 2.3 & 0.9 & 1.5 \\
\hline Japan $^{\mathrm{d}}$ & 14.0 & 3.3 & 72.2 & 6.2 & 0.7 & 3.6 \\
\hline China $^{c}$ & 9.2 & 0.6 & 0.9 & 81.1 & 0.1 & 8.0 \\
\hline Australia $^{\mathrm{e}}$ & 13.0 & 4.8 & 2.3 & 2.1 & 77.3 & 0.4 \\
\hline Rest of world & 3.4 & 3.9 & 2.6 & 2.8 & 0.1 & 87.2 \\
\hline
\end{tabular}

a These shares sum to 100 horizontally. They are based on 2016 investment flows. The original flow matrix is inconsistent with data on saving and investment from national accounts and so a RAS algorithm is used to ensure that row and column sums are consistent with other data. The row sums of the flow matrix are total saving by region and the column sums are total investment by region. These sums are sourced from the IMF-IFS database and the World Bank database.

b USA: values are based on official statistics, BEA.

c EU and China: indirect information from USA, Australian and Japanese statistics.

d Japan: estimated based on FDI data, assuming investment outflow=FDI*1.6. The ratio 1.6 is that of USA reported inward investment from Japan divided by Japanese reported outward FDI to the USA.

e Australia: Australian Bureau of Statistics "International Investment Position, Australia: Supplementary Statistics, 2016".

$\mathrm{f}$ ROW is a residual. Its saving is inferred from national accounts estimates and its investment abroad is determined to balance the matrix of financial flows. 
Table 3: Simulation Closures ${ }^{\mathrm{a}}$

\begin{tabular}{lll}
\hline Closure & Short run & Long run \\
\hline Labour market: & $\begin{array}{l}\text { Exogenous nominal low-skill wage with } \\
\text { endogenous employment }\end{array}$ & $\begin{array}{l}\text { Constant unemployment rate with } \\
\text { endogenous low-skill wage }\end{array}$ \\
Fiscal policy: & $\begin{array}{l}\text { Exogenous nominal government spending on } \\
\text { goods and services with endogenous } \\
\text { government revenue at fixed rates of tax on } \\
\text { income, consumption and trade }\end{array}$ & $\begin{array}{l}\text { Exogenous nominal government } \\
\text { spending on goods and services } \\
\text { and fiscal balance with endogenous } \\
\text { rates of tax on consumption } \\
\text { expenditure }\end{array}$ \\
$\begin{array}{l}\text { Investment and } \\
\text { capital: }\end{array}$ & $\begin{array}{l}\text { Exogenous physical capital stock with } \\
\text { endogenous investment and expected rates } \\
\text { of return }\end{array}$ & $\begin{array}{l}\text { Endogenous physical capital stock } \\
\text { and investment with exogenous } \\
\text { expected rates of return }\end{array}$ \\
$\begin{array}{l}\text { Monetary policy } \\
\text { targets }\end{array}$ & $\begin{array}{l}\text { Advanced economies: Consumer price level } \\
\text { China and the Rest of the World: Fixed exchange rates against the US\$ }\end{array}$ \\
& $\begin{array}{l}\text { Alternate case to estimate counterfactual deflation: money supplies fixed in all } \\
\text { regions }\end{array}$ & \\
\hline
\end{tabular}

a Since the model is a system of non-linear simultaneous equations and more variables are specified than equations in the system, there is flexibility as to the choice of those to make exogenous. This choice mirrors assumptions about the behaviour of labour markets, fiscal deficits, investment and monetary policy targets. b Money supplies can be set to target any of the three price levels (consumer, producer and GDP), nominal exchange rates against the US\$ or nominal GDP levels.

c The US\$ is the numeraire in the model, which calculates exchange rates against it and also effective exchange rates.

$\mathrm{d}$ No changes in commercial bank reserve behaviour are assumed so that money multipliers remain constant.

Table 4: Growth Surge Shocks ${ }^{\mathrm{a}}$

\begin{tabular}{lr}
\hline$\%$ & \\
\hline & 5 \\
Total factor productivity, $A^{V}$ & 2 \\
Total factor and input productivity, $A^{Y}$ & -10 \\
Consumption constant, $A^{C}$ & 6 \\
Skill stock, $S^{K}$ & 8 \\
Capital stock $^{\mathrm{b}}, K$ &
\end{tabular}

a All shocks are to the Chinese economy only.

$\mathrm{b}$ In the long run the capital stock is endogenous to fixed expected rates of return and so it is not shocked.

Source: Authors' approximations as to primary shocks during the peak growth surge years 2002 to 2006 . 
Table 6: Sensitivity of the Effects of the Growth Surge to Type 2 Financial Integration ${ }^{\text {a,b }}$

\begin{tabular}{|c|c|c|c|c|c|}
\hline$\%$ changes due to $\sigma_{i}^{I}=2,20$ & & US & $\mathrm{EU}(26)$ & Japan & China \\
\hline \multirow[t]{2}{*}{ Real bond yield, $r$} & Short run & 10 & 6 & 6 & -25 \\
\hline & Long run ${ }^{c}$ & 13 & 7 & 6 & -32 \\
\hline \multirow{2}{*}{ Money supply, $M_{S}$} & Short run & 9 & 5 & 4 & -67 \\
\hline & Long run ${ }^{c}$ & 12 & 5 & 5 & -77 \\
\hline \multirow{2}{*}{$\begin{array}{l}\text { Consumer price level, } P^{C} \\
\text { ( } M_{S} \text { target all regions) }\end{array}$} & Short run & 61 & $1010^{d}$ & 7 & -20 \\
\hline & Long run ${ }^{\mathrm{b}}$ & 53 & $-121^{d}$ & 4 & -35 \\
\hline \multirow[t]{2}{*}{ CA balance, $\%$ GDP } & Short run & 12 & 7 & 5 & 15 \\
\hline & Long run ${ }^{c}$ & 14 & 7 & 9 & 18 \\
\hline \multirow[t]{2}{*}{ Real output (GDP), $Y / P^{Y}$} & Short run & 7 & 2 & 2 & -6 \\
\hline & Long run ${ }^{c}$ & 8 & 0 & -4 & -2 \\
\hline Real disposable income & Short run & 7 & 2 & 2 & -7 \\
\hline$Y_{D} / P^{C}$ & Long run ${ }^{\mathrm{c}}$ & 9 & 2 & 3 & -16 \\
\hline
\end{tabular}

a The numbers indicate the proportional change in the effects of the growth surge detailed in Table 5 due to the sweep of the Chinese elasticity of asset substitution between $\sigma_{i}^{I}=2$ and $\sigma_{i}^{I}=20$.

$\mathrm{b}$ These results are from the model described in the text with the closures and shocks listed in Tables 3 and 4 . In particular, the default monetary target for all the advanced economies is the domestic consumer price level while China and the rest of the world adopt the bilateral exchange rate with the US. The results shown for $P^{C}$ are, however, from the alternative monetary policy closure that has all regions targeting their money supplies. The "moderate" financial integration parameters referred to are values of the elasticity of substitution between assets for each region, $\sigma_{i}^{I}$. These are US: 15, EU: 15, Japan: 10, China: 5, Australia: 15, Rest of World: 5.

c The long run simulations maintain constant employment while allowing financial flows to deliver changes in capital stocks and hence adjustments in production capacity. Fiscal balance is maintained by adjusting tax rates on consumption expenditure.

$\mathrm{d}$ The large proportional changes in EU deflation stem from very small denominators, due to the very small effects of the surge on EU price levels shown in the previous table.

Source: Simulations of the model described in the text. 
Editor, UWA Economics Discussion Papers:

Sam Hak Kan Tang

University of Western Australia

35 Sterling Hwy

Crawley WA 6009

Australia

Email: ecoadmin@biz.uwa.edu.au

The Economics Discussion Papers are available at:

Since 1980: $\quad$ https://ideas.repec.org/s/uwa/wpaper.html

Since 2004: http://www.business.uwa.edu.au/school/disciplines/economics

\begin{tabular}{|c|c|c|}
\hline \multicolumn{3}{|c|}{ ECONOMICS DISCUSSION PAPERS - 2016} \\
\hline $\begin{array}{l}\text { DP } \\
\text { NUMBER }\end{array}$ & AUTHORS & TITLE \\
\hline 16.01 & Xu, R., Wu, Y. and Luan, J. & $\begin{array}{l}\text { ANALYSIS OF FARMERS’ WILLINGNESS TO ADOPT } \\
\text { GENETICALLY MODIFIED INSECT-RESISTANT RICE IN } \\
\text { CHINA }\end{array}$ \\
\hline 16.02 & $\begin{array}{l}\text { Lia, Y., Fan, J., Zhao, D., Wu, Y. and } \\
\text { Li, J. }\end{array}$ & $\begin{array}{l}\text { TIERED GASOLINE PRICING: A PERSONAL CARBON } \\
\text { TRADING PERSPECTIVE }\end{array}$ \\
\hline 16.03 & Clements, K.W., Lan, Y. and Si, J. & UNCERTAINTY IN CURRENCY MISPRICING \\
\hline 16.04 & Parsons, C. and Vézina, P.L. & $\begin{array}{l}\text { MIGRANT NETWORKS AND TRADE:THE VIETNAMESE } \\
\text { BOAT PEOPLE AS A NATURAL EXPERIMENT }\end{array}$ \\
\hline 16.05 & Chang, S., Connelly, R. and Ma, P. & $\begin{array}{l}\text { WHAT WILL YOU DO IF I SAY 'I DO’?: THE EFFECT OF } \\
\text { THE SEX RATIO ON TIME USE WITHIN TAIWANESE } \\
\text { MARRIED COUPLES }\end{array}$ \\
\hline 16.06 & Yu, F. and Wu, Y. & $\begin{array}{l}\text { BIASES IN PATENT EXAMINATION AND FIRMS’ } \\
\text { RESPONSES: EVIDENCE FROM THE } \\
\text { PHARMACEUTICAL INDUSTRY }\end{array}$ \\
\hline 16.07 & $\begin{array}{l}\text { Fan, J., Li, J., Wu, Y., Wang, S. and } \\
\text { Zhao, D. }\end{array}$ & $\begin{array}{l}\text { THE EFFECTS OF ALLOWANCE PRICE ON ENERGY } \\
\text { DEMAND UNDER A PERSONAL CARBON TRADING } \\
\text { SCHEME }\end{array}$ \\
\hline 16.08 & Golley, J., Tyers, R. and Zhou, Y. & $\begin{array}{l}\text { CONTRACTIONS IN CHINESE FERTILITY AND } \\
\text { SAVINGS: LONG RUN DOMESTIC AND GLOBAL } \\
\text { IMPLICATIONS }\end{array}$ \\
\hline 16.09 & McGrath, G. and Neill, K. & $\begin{array}{l}\text { FOREIGN AND DOMESTIC OWNERSHIP IN WESTERN } \\
\text { AUSTRALIA'S GAS MARKET }\end{array}$ \\
\hline 16.10 & Clements, K.W. and Si, J. & SIMPLIFYING THE BIG MAC INDEX \\
\hline 16.11 & Priyati, R.Y. and Tyers, R. & $\begin{array}{l}\text { PRICE RELATIONSHIPS IN VEGETABLE OIL AND } \\
\text { ENERGY MARKETS }\end{array}$ \\
\hline 16.12 & Wu, J., Wu, Y. and Wang, B. & $\begin{array}{l}\text { THE GREENNESS OF CHINESE CITIES: CARBON } \\
\text { DIOXIDE EMISSION AND ITS DETERMINANTS }\end{array}$ \\
\hline 16.13 & $\begin{array}{l}\text { Arslan, C., Dumont, J.C., Kone, Z., } \\
\text { Özden, Ç., Parsons, C. and } \\
\text { Xenogiani, T. }\end{array}$ & $\begin{array}{l}\text { INTERNATIONAL MIGRATION TO THE OECD IN THE } \\
\text { TWENTY-FIRST CENTURY }\end{array}$ \\
\hline 16.14 & Tomioka, K. and Tyers, R. & $\begin{array}{l}\text { HAS FOREIGN GROWTH CONTRIBUTED TO } \\
\text { STAGNATION AND INEQUALITY IN JAPAN? }\end{array}$ \\
\hline 16.15 & Donovan, J. and Hartley, P. & RIDING THE IRON ORE CYCLE: ACTIONS OF \\
\hline
\end{tabular}




\begin{tabular}{|l|l|l|}
\hline 16.16 & Czaika, M. and Parsons, C. & $\begin{array}{l}\text { AUSTRALIA'S MAJOR PRODUCERS } \\
\text { HIGH-SKILLED MIGRATION IN TIMES OF GLOBAL } \\
\text { ECONOMIC CRISIS }\end{array}$ \\
\hline 16.17 & Lefroy, T., Key, J. and Kingwell, R. & $\begin{array}{l}\text { A LONGITUDINAL EXAMINATION OF BROADACRE } \\
\text { FARM SIZE AND PERFORMANCE IN WESTERN } \\
\text { AUSTRALIA }\end{array}$ \\
\hline 16.18 & Arthmar, R. and McLure, M. & $\begin{array}{l}\text { SRAFFA, MYRDAL AND THE 1961 SÖDERSTRÖM GOLD } \\
\text { MEDAL }\end{array}$ \\
\hline 16.19 & Azwar, P. and Tyers, R. & $\begin{array}{l}\text { POST-GFC EXTERNAL SHOCKS AND INDONESIAN } \\
\text { ECONOMIC PERFORMANCE }\end{array}$ \\
\hline 16.20 & Chen, A. and Groenewold, N. & $\begin{array}{l}\text { OUTPUT SHOCKS IN CHINA: DO THE DISTRIBUTIONAL } \\
\text { EFFECTS DEPEND ON THE REGIONAL SOURCE? }\end{array}$ \\
\hline 16.21 & Wu, Y., Zhu, X. and Groenewold, N. & $\begin{array}{l}\text { THE DETERMINANTS AND EFFECTIVENESS OF } \\
\text { INDUSTRIAL POLICY IN CHINA: A STUDY BASED ON } \\
\text { FIVE-YEAR PLANS }\end{array}$ \\
\hline 16.22 & Liu, H. & $\begin{array}{l}\text { THE INCOME AND PRICE SENSITIVITY OF DIETS } \\
\text { GLOBALLY }\end{array}$ \\
\hline 16.23 & Asano, A., Neill, K. and Yamazaki, S. & $\begin{array}{l}\text { DECOMPOSING FISHING EFFORT: MODELLING THE } \\
\text { SOURCES OF INEFFICIENCY IN A LIMITED-ENTRY } \\
\text { FISHERY }\end{array}$ \\
\hline 16.24 & Golley, J., Tyers, R. and Zhou, Y. & $\begin{array}{l}\text { FERTILITY AND SAVINGS CONTRACTIONS IN CHINA: } \\
\text { LONG-RUN GLOBAL IMPLICATIONS }\end{array}$ \\
\hline 16.25 & Taylor, G., Tyers, R. & $\begin{array}{l}\text { SECULAR STAGNATION: DETERMINANTS AND } \\
\text { CONSEQUENCES FOR AUSTRALIA }\end{array}$ \\
\hline
\end{tabular}

\begin{tabular}{|c|c|c|}
\hline \multicolumn{3}{|c|}{ ECONOMICS DISCUSSION PAPERS - 2017} \\
\hline $\begin{array}{c}\text { DP } \\
\text { NUMBER }\end{array}$ & AUTHORS & TITLE \\
\hline 17.01 & Tyers, R. and Zhou, Y. & $\begin{array}{l}\text { AUTOMATION AND INEQUALITY WITH TAXES AND } \\
\text { TRANSFERS }\end{array}$ \\
\hline 17.02 & Ye, L. and Robertson, P. & $\begin{array}{l}\text { HITTING THE GREAT WALL: RURAL-URBAN } \\
\text { MIGRATION AND CHINA'S GROWTH SLOWDOWN }\end{array}$ \\
\hline 17.03 & Ye, L. and Robertson, P. & $\begin{array}{l}\text { MIGRATION AND GROWTH IN CHINA: A SCEPTICAL } \\
\text { ASSESSMENT OF THE EVIDENCE }\end{array}$ \\
\hline 17.04 & Clements, K. Si, J. and Vo, L. & $\begin{array}{l}\text { FOOD AND AGRICULTURAL PRICES ACROSS } \\
\text { COUNTRIES AND THE LAW OF ONE PRICE }\end{array}$ \\
\hline 17.05 & $\begin{array}{l}\text { Chen, M., Clements, K., Gao, G. and } \\
\text { Si, J. }\end{array}$ & THREE FACTS ABOUT WORLD METAL PRICES \\
\hline 17.06 & $\begin{array}{l}\text { Cornes, R., Fiorini, L. and } \\
\text { Maldonado, W. }\end{array}$ & $\begin{array}{l}\text { EXPECTATIONAL STABILITY IN AGGREGATIVE } \\
\text { GAMES }\end{array}$ \\
\hline 17.07 & Hartley, P. & $\begin{array}{l}\text { THE COST OF DISPLACING FOSSIL FUELS: SOME } \\
\text { EVIDENCE FROM TEXAS }\end{array}$ \\
\hline 17.08 & Shehabi, M. R. & ASSESSING KUWAITI ENERGY PRICINING REFORMS \\
\hline 17.09 & Perdana, S. and Tyers, R. & $\begin{array}{l}\text { GLOBAL CLIMATE CHANGE MITIGATION: STRATEGIC } \\
\text { INTERACTION OR UNILATERAL GAINS? }\end{array}$ \\
\hline 17.10 & McLure, M. & $\begin{array}{l}\text { RICARDIAN EQUIVALENCE, THE ITALIAN FISCAL } \\
\text { TRADITION AND WA GOVERNMENT NET DEBT }\end{array}$ \\
\hline 17.11 & Trinh, J. & $\begin{array}{l}\text { THE PARETO DISTRIBUTION AND ITS RELATIONSHIP } \\
\text { TO PIKETTY'S THIRD FUNDAMENTAL LAW OF } \\
\text { CAPITALISM }\end{array}$ \\
\hline 17.12 & McLure, M. & THINKING OUTSIDE THE BOX: A NEW HISTORY OF \\
\hline
\end{tabular}




\begin{tabular}{|c|c|c|}
\hline & & $\begin{array}{l}\text { EDGEWORTH'S AND PARENTO'S DEVELOPMENT OF } \\
\text { THE BOX DIAGRAM }\end{array}$ \\
\hline 17.13 & Zhou, Y. and Tyers, R. & AUTOMATION AND INEQUALITY IN CHINA \\
\hline 17.14 & Arthmar, R. and McLure, M. & $\begin{array}{l}\text { THE ECONOMIC AND SOCIAL CONSEQUENCES OF THE } \\
\text { WAR: PIGOU, THE PRESS AND THE STRUGGLE FOR AN } \\
\text { HONOURABLE PEACE }\end{array}$ \\
\hline 17.15 & Shehabi, M. R. & $\begin{array}{l}\text { CONTEMPORARY KUWAITISATION DYNAMICS AND } \\
\text { THEIR HISTORICAL PERSPECTIVES }\end{array}$ \\
\hline 17.16 & Clements, K. and Si, J. & $\begin{array}{l}\text { WHAT DO AUSTRALIAN ECONOMICS PhDs DO? THE } \\
\text { UWA EXPERIENCE }\end{array}$ \\
\hline 17.17 & Arthmar, R. and McLure, M. & KEYNES AND THE ROYAL SWEDISH ACADEMY \\
\hline 17.18 & Chen, A. and Groenewold, N. & $\begin{array}{l}\text { CHINA’S ‘NEW NORMAL’: IS THE GROWTH } \\
\text { SLOWDOWN DEMAND- OR SUPPLY- DRIVEN? }\end{array}$ \\
\hline 17.19 & Groenewold, N. & $\begin{array}{l}\text { CHINA'S ‘NEW NORMAL’: HOW WILL CHINA’S } \\
\text { GROWTH SLOWDOWN AFFECT AUSTRALIA'S } \\
\text { GROWTH? }\end{array}$ \\
\hline
\end{tabular}

ECONOMICS DISCUSSION PAPERS - 2018

\begin{tabular}{|c|c|c|}
\hline $\begin{array}{c}\text { DP } \\
\text { NUMBER }\end{array}$ & AUTHORS & TITLE \\
\hline 18.01 & Tyers, R. and Zhou, Y. & LOST INFLATION? \\
\hline 18.02 & McLure, M. & PARETIAN FISCAL SOCIOLOGY \\
\hline 18.03 & McLure, M. and Montesano, A. & $\begin{array}{l}\text { THINKING OUTSIDE THE BOX: EDGEWORTH, PARETO } \\
\text { AND THE EARLY HISTORY OF THE BOX DIAGRAM }\end{array}$ \\
\hline 18.04 & Tyers, R. and Zhou, Y. & DEFLATION FORCES AND INEQUALITY \\
\hline 18.05 & Clements, K. and Si, J. & DIVISIA AND FRISCH ARE FRIENDS \\
\hline 18.06 & Trinh, J. and McLure, M. & $\begin{array}{l}\text { PILETTY'S }(\mathrm{r}-\mathrm{g}) \text { LAW IS PARETO'S LAW: CONSISTENT } \\
\text { ANALYSES OF INCOME DISTRIBUTION PREDICATED ON } \\
\text { INCONSISTENT DEFINITIONS OF INEQUALITY }\end{array}$ \\
\hline 18.07 & Tyers, R. and Zhou, Y. & $\begin{array}{l}\text { AUTOMATION, TAXES AND TRANSFERS } \\
\text { WITH INTERNATIONAL RIVALRY }\end{array}$ \\
\hline 18.08 & Li, Q., Vo, L. H. and Wu, Y. & INTANGIBLE CAPITAL DISTRIBUTION IN CHINA \\
\hline 18.09 & Vo, L. H. & $\begin{array}{l}\text { WHY DON'T AGRICULTURAL PRICES ALWAYS ADJUST } \\
\text { TOWARDS PARITY? }\end{array}$ \\
\hline 18.10 & Magnusson, L. M. and Tarverdi, Y. & MEASURING GOVERNANCE: WHY DO ERRORS MATTER? \\
\hline
\end{tabular}

